\title{
Effect of Extraction Conditions on the Antioxidant Activity of Olive Wood Extracts
}

\author{
Mercedes Pérez-Bonilla, ${ }^{1}$ Sofía Salido, ${ }^{1}$ Adolfo Sánchez, ${ }^{1}$ \\ Teris A. van Beek, ${ }^{2}$ and Joaquín Altarejos ${ }^{1}$ \\ ${ }^{1}$ Departamento de Química Inorgánica y Orgánica, Facultad de Ciencias Experimentales, Universidad de Jaén, \\ Campus de Excelencia Internacional Agroalimentario, ceiA3, 23071 Jaén, Spain \\ ${ }^{2}$ Laboratory of Organic Chemistry, Natural Products Chemistry Group, Wageningen University, Dreijenplein 8, \\ 6703 HB Wageningen, The Netherlands
}

Correspondence should be addressed to Joaquín Altarejos; jaltare@ujaen.es

Received 12 February 2013; Accepted 28 March 2013

Academic Editor: Philip Cox

Copyright ( 2013 Mercedes Pérez-Bonilla et al. This is an open access article distributed under the Creative Commons Attribution License, which permits unrestricted use, distribution, and reproduction in any medium, provided the original work is properly cited.

\begin{abstract}
An investigation to optimize the extraction yield and the radical scavenging activity from the agricultural by-product olive tree wood (Olea europaea L., cultivar Picual) using six different extraction protocols was carried out. Four olive wood samples from different geographical origin, and harvesting time have been used for comparison purposes. Among the fifty olive wood extracts obtained in this study, the most active ones were those prepared with ethyl acetate, either through direct extraction or by successive liquid-liquid partitioning procedures, the main components being the secoiridoids oleuropein and ligustroside. An acid hydrolysis pretreatment of olive wood samples before extractions did not improve the results. In the course of this study, two compounds were isolated from the ethanolic extracts of olive wood collected during the olives' harvesting season and identified as $\left(7^{\prime \prime} R\right)-7^{\prime \prime}$ ethoxyoleuropein (1) and ( $\left.7^{\prime \prime} S\right)-7^{\prime \prime}$-ethoxyoleuropein (2).
\end{abstract}

\section{Introduction}

Since agricultural and industrial residues are attractive sources of natural antioxidants, basically due to their null or low value [1-4], different residues and by-products from fruits $[5,6]$, vegetables $[7,8]$, or olive oil manufacturing [9] have been screened for the presence of antioxidants. Due to the large amounts of biomass from pruning generated every year (more than 7 million tonnes per year in Spain), olive tree wood constitutes an important agricultural by-product. During the search of natural antioxidants from Olea europaea L. residues and by-products, both solid and liquid residues from olive oil and table olives processing have been studied $[2,10-19]$.

Our preliminary studies on the radical scavenging activity of olive wood extracts, cultivar Picual, showed that this agricultural by-product could be a source of natural antioxidants [20]. The isolation and radical scavenging activity of the main constituents [21] as well as some minor components present in olive wood extracts have been reported by us [22]. The secoiridoids oleuropein and ligustroside are among the main components. Other compounds present in olive wood are the lignan (+)-cycloolivil, the phenolic alcohol hydroxytyrosol, and several secoiridoids related to oleuropein, such as $\left(7^{\prime \prime} S\right)$ $7^{\prime \prime}$-hydroxyoleuropein or oleuropein $3^{\prime}-O-\beta$-D-glucoside. Moreover, the human platelet antiaggregant properties of two olive wood components, oleuropein and $(+)$-cycloolivil, have been evaluated [23]. The cultivar Picual was selected for these studies since it is one of the most important Spanish olive varieties for oil extraction, representing around 860.000 ha in the province of Jaén and other Andalusian areas, and is also cultivated in other regions of Spain and other countries [24].

Solvent extraction is routinely used for the isolation of antioxidants from plant material. Both extraction yield and antioxidant activity of extracts are strongly dependent on the solvent [1]. Hence, a comparative study for selecting optimal extraction conditions to provide the highest antioxidant activity (and proper extraction yield) from olive wood 
(cultivar Picual) was carried out in this work. For this purpose several extraction processes at room temperature and reflux were designed using solvents of different polarities. Also the influence of an acidic hydrolysis pretreatment of olive wood was investigated, since this methodology has been used sometimes to improve the recovery of phenols [3].

\section{Materials and Methods}

2.1. Chemicals. The solvents used for extraction (hexane, dichloromethane, ethyl acetate, $n$-butanol, ethanol, methanol, chloroform, and acetone) were glass-distilled prior to use. Methanol used for radical scavenging activity assays was of HPLC grade. Deuterated methanol was used to prepare solutions of purified compounds for NMR analysis. The 2,2diphenyl-1-picrylhydrazyl radical $\left(\mathrm{DPPH}^{\circ}\right.$, 95\%) was purchased from Sigma-Aldrich Chemie (Steinheim, Germany). A commercial rosemary oleoresin was obtained from Evesa (Cádiz, Spain).

2.2. General Experimental Procedures. Optical rotations $\left([\alpha]_{\mathrm{D}}\right)$ were recorded in $\mathrm{MeOH}$ on a Perkin-Elmer 241 automatic polarimeter (Perkin-Elmer Instruments, Norwalk, CT, USA), in a $10 \mathrm{~cm} 2 \mathrm{~mL}$ cell. Ultraviolet (UV) spectra were recorded in $\mathrm{MeOH}$ on a Perkin-Elmer UV/Vis spectrophotometer Lambda 19 (Perkin-Elmer Instruments, Norwalk, CT, USA). Infrared (IR) spectra were recorded on a FTIR Perkin-Elmer 1760X spectrometer (Perkin-Elmer Instruments, Norwalk, CT, USA). NMR spectra $\left({ }^{1} \mathrm{H} \mathrm{NMR},{ }^{13} \mathrm{C}\right.$ NMR, DQF-COSY, HSQC, HMBC) were recorded on a Bruker Avance AMX 500 spectrometer (Bruker Daltonik $\mathrm{GmbH}$, Rheinstetten, Germany), using $\mathrm{CD}_{3} \mathrm{OD}$ as solvent and tetramethylsilane (TMS) as internal reference. Mass spectra (MS) were recorded on an Finnigan MAT LCQ ion trap mass spectrometer (Waters Integrity System, Milford, MA, USA). The ESI interface was used in both positive and negative modes, with the capillary temperature at $200^{\circ} \mathrm{C}$ and a spray voltage of $4.5 \mathrm{kV}$.

High-performance liquid chromatography (HPLC) analyses were performed on an analytical RP-HPLC Spherisorb ODS-2 column $(250 \mathrm{~mm} \times 3 \mathrm{~mm}$ i.d., $5 \mu \mathrm{m})$ (Waters Chromatography Division, Milford, MA, USA) on a Waters 600E instrument (Waters Chromatography Division, Milford, MA, USA) equipped with a diode array detector, scan range: 190-800 nm (Waters CapLC 2996 Photodiode Array Detector, Waters Chromatography Division, Milford, MA, USA), and operating at $30^{\circ} \mathrm{C}$. Samples of the extracts were prepared in $\mathrm{MeOH}$ at a concentration of $10 \mathrm{mg} \mathrm{mL}^{-1}$, and the injection volume was $10 \mu \mathrm{L}$. The best separation was performed with $\mathrm{H}_{2} \mathrm{O}: \mathrm{CH}_{3} \mathrm{COOH}, 99.8: 0.2$, v/v (solvent A) and $\mathrm{CH}_{3} \mathrm{OH}: \mathrm{CH}_{3} \mathrm{COOH}, 99.8: 0.2$, v/v (solvent $\mathrm{B}$ ), at a flow rate of $0.7 \mathrm{~mL} \mathrm{~min}^{-1}$, using a linear gradient from $20 \%$ to $70 \%$ $\mathrm{B}$ for $55 \mathrm{~min}$. The HPLC analyses were recorded at $230 \mathrm{~nm}$, since most of the compounds present in olive extracts have an intense absorption at that wavelength.

Preparative HPLC separations were performed on an Alltima C18 column $(250 \mathrm{~mm} \times 22 \mathrm{~mm}$ i.d., $5 \mu \mathrm{m})$ (Alltech Associates Inc., Deerfield, IL, USA) with a Shimadzu preparative HPLC instrument (Shimadzu, Kyoto, Japan), equipped with a diode array detector, scan range: 190-600 nm (SPDM10Ap Photodiode Array Detector, Shimadzu, Kyoto, Japan) and a sample collector FRC-10 A (Shimadzu, Kyoto, Japan), and operating at $30^{\circ} \mathrm{C}$ and a flow rate of $12 \mathrm{~mL} \mathrm{~min}^{-1}$ with $\mathrm{H}_{2} \mathrm{O}: \mathrm{CH}_{3} \mathrm{OH}: \mathrm{CH}_{3} \mathrm{COOH}(59.9: 39.9: 0.2$, v/v/v).

HPLC-DAD-MS analyses were performed on an Spherisorb ODS- 2 column $(125 \mathrm{~mm} \times 3 \mathrm{~mm}$ i.d., $5 \mu \mathrm{m})$ (Waters Chromatography Division, Milford, MA, USA) with an Agilent 1100 HPLC instrument (Agilent Technologies, Santa Clara, CA, USA) equipped with a diode array detector, scan range: 190-600 nm (G1315B Photodiode Array Detector, Agilent Technologies, Santa Clara, CA, USA) and an ion trap mass spectrometer Esquire 6000 (Bruker Daltonics, Bremen, Germany). The sample preparation and gradient were the same as those in the HPLC analysis. The flow rate was $0.4 \mathrm{~mL} \mathrm{~min}^{-1}$. The ESI source parameters were as follows: capillary voltage: $4 \mathrm{kV}$; cap exit: $-100 \mathrm{~V}$; skimmer: $-40 \mathrm{~V}$; trap drive: 70; nebulizer: 50 psi; dry gas: $10 \mathrm{~mL} \mathrm{~min}^{-1}$; dry temperature: $350^{\circ} \mathrm{C}$; scan range: $m / z 50-1000$.

2.3. Plant Material and Collection Data. Four samples of olive wood (Olea europaea L., cultivar Picual) were collected at two olive groves located in Jaén province (southern Spain) during the pruning period (March and April) and at the beginning of the olives' harvesting season (November) from 2003 until 2006. The samples collected were labelled as A, $\mathbf{B}, \mathbf{C}$, and $\mathbf{D}$, and the location and collection date were as follows: A (Fuensanta village; April, 2003), B (Fuensanta village; March, 2005), C (Mogón village; March, 2005), and D (Fuensanta village; November, 2006). In each case, the plant material consisted of a single piece of $c a .10 \mathrm{~cm}$ diameter and $50 \mathrm{~cm}$ length from the pruning of the same olive grove near Fuensanta (A, B) and a different olive grove near Mogón (C). Another similar single piece was cut in the same olive grove near Fuensanta during the olives' harvesting season for comparison (D). Each sample was stored in a dry and dark place at room temperature with passive ventilation for 3 months. Just before starting the extraction process, the samples (including bark and heartwood) were scraped in a local sawmill (wood shavings: length $3-5 \mathrm{~cm}$, thickness $0.1-0.3 \mathrm{~mm}$ ).

2.4. Extraction Protocols. Olive wood samples A, B, C, and D were extracted by the following procedures $(i-i v)$.

(i) Procedures E1, E2, and E3. These procedures involved the sequential extraction of olive wood samples with solvents of increasing polarity at room temperature for $24 \mathrm{~h}$ or under reflux for $2 \mathrm{~h}$. The procedure E1 employed the sequence of solvents $\mathrm{CH}_{2} \mathrm{Cl}_{2}$ and $\mathrm{EtOH}$ at room temperature (Figure 1). The procedure E2 used the sequence of solvents $n$-hexane, $\mathrm{CH}_{2} \mathrm{Cl}_{2}, \mathrm{EtOAc}$, and EtOH at room temperature (Figure 2). The procedure $\mathrm{E} 3$ employed $\mathrm{CH}_{2} \mathrm{Cl}_{2}$ at room temperature and then EtOAc under reflux (Figure 3). The olive wood sample A (35 g each) was extracted by the procedures E1 and E2 using $250 \mathrm{~mL}$ of each solvent (extracts A1-A3; see Table 2). Olive wood samples A, B, C, and D (35 g each) were extracted by the procedure E3 using $500 \mathrm{~mL}$ of each solvent (extracts A4, B1, C1, and D1; see Tables 2 and 4). The extracts prepared 


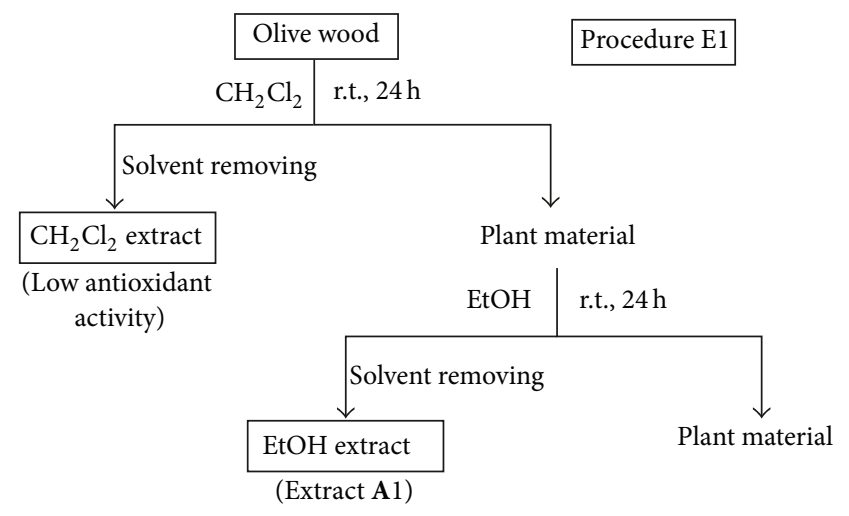

Figure 1: Solvent extractions of olive wood sample A following procedure E1.

with $n$-hexane and $\mathrm{CH}_{2} \mathrm{Cl}_{2}$ were discarded since their radical scavenging activities were low.

(ii) Procedure E4. This procedure involved the direct extraction of olive wood samples with different solvents at room temperature for $24 \mathrm{~h}$ and under reflux for $2 \mathrm{~h}$ (Figure 4$)$. The solvents used were EtOAc, EtOH, EtOH: $\mathrm{H}_{2} \mathrm{O}(3: 2, \mathrm{v} / \mathrm{v})$, $\mathrm{H}_{2} \mathrm{O}$, and $\mathrm{H}_{2} \mathrm{O}: \mathrm{HCOOH}(4: 1, \mathrm{v} / \mathrm{v})$. The olive wood sample $\mathbf{A}$ $(35 \mathrm{~g})$ was extracted by the procedure $\mathrm{E} 4$ at room temperature (A5-A9) and under reflux using $500 \mathrm{~mL}$ of each solvent (A10-A14) (Table 2). The olive wood samples B, C, and D ( $35 \mathrm{~g}$ each) were extracted by the procedure $\mathrm{E} 4$ using $500 \mathrm{~mL}$ of EtOH under reflux (extracts B2, C2, and D2) (Table 4).

(iii) Procedures E5 and E6. These procedures involved the direct extraction of olive wood samples with a polar solvent under reflux for $2 \mathrm{~h}$, followed by a liquid-liquid partitioning of the resulting extract with solvents of increasing polarity (Figures 5 and 6). A mixture of $\mathrm{EtOH}: \mathrm{H}_{2} \mathrm{O}(3: 2, \mathrm{v} / \mathrm{v})$ was used for the direct extraction in procedure E5 (Figure 5), while $\mathrm{MeOH}$ was used in procedure E6 (Figure 6). Olive wood sample A ( $30 \mathrm{~g})$ was extracted by the procedure E5 using $350 \mathrm{~mL}$ of EtOH : $\mathrm{H}_{2} \mathrm{O}(3: 2)$. The resulting EtOH $: \mathrm{H}_{2} \mathrm{O}$ extract was evaporated to dryness under vacuum, suspended in water $(200 \mathrm{~mL})$, and successively liquid-liquid partitioned with EtOAc $(150 \mathrm{~mL})$ and $n-\mathrm{BuOH}(150 \mathrm{~mL})$ to yield extracts A15 and A16, respectively (Figure 5 and Table 2). The remaining aqueous phase was also evaporated to yield extract A17. Another olive wood sample A ( $30 \mathrm{~g})$ was extracted by the procedure E6 using $350 \mathrm{~mL}$ of $\mathrm{MeOH}$. In a similar manner, the resulting $\mathrm{MeOH}$ extract was evaporated and partitioned with $\mathrm{Et}_{2} \mathrm{O}(150 \mathrm{~mL}), \mathrm{CHCl}_{3}(150 \mathrm{~mL})$, and $n-\mathrm{BuOH}(150 \mathrm{~mL})$ to yield extracts A18, A19, and A20, respectively (Figure 6, Table 2).

(iv) Procedure E7. This procedure involved an acidic hydrolysis pretreatment of the olive wood samples using different acids for $1 \mathrm{~h}, 3 \mathrm{~h}$, and $5 \mathrm{~h}$ at $130^{\circ} \mathrm{C}$, followed by a solvent extraction of both the resulting liquid acidic extract and solid pretreated wood (Figure 7). Every olive wood sample A (5 g each) was hydrolysed with $40 \mathrm{~mL}$ of $0.5 \mathrm{M} \mathrm{H}_{2} \mathrm{SO}_{4}$ in $\mathrm{H}_{2} \mathrm{O}, 40 \mathrm{~mL}$ of $0.5 \mathrm{M} \mathrm{H}_{2} \mathrm{SO}_{4}$ in EtOH: $\mathrm{H}_{2} \mathrm{O}(1: 1, \mathrm{v} / \mathrm{v}), 40 \mathrm{~mL}$ of $1 \mathrm{M} \mathrm{HCl}$ in $\mathrm{H}_{2} \mathrm{O}$, or $40 \mathrm{~mL}$ of $1 \mathrm{M} \mathrm{HCl}$ in $\mathrm{EtOH}: \mathrm{H}_{2} \mathrm{O}$ $(1: 1, \mathrm{v} / \mathrm{v})$ under the conditions described above. Thus, for example, an olive wood sample $\mathbf{A}(5 \mathrm{~g})$ was pretreated with $40 \mathrm{~mL}$ of $0.5 \mathrm{M} \mathrm{H}_{2} \mathrm{SO}_{4}$ in $\mathrm{H}_{2} \mathrm{O}$ for $1 \mathrm{~h}$ at $130^{\circ} \mathrm{C}$. Then, the mixture was filtered, and the liquid acidic extract diluted with water $(200 \mathrm{~mL})$ and its $\mathrm{pH}$ adjusted to 3 with $\mathrm{Na}_{2} \mathrm{CO}_{3}$. EtOAc $(100 \mathrm{~mL})$ were added to the acidic aqueous phase and refluxed for $0.5 \mathrm{~h}$. Then, the EtOAc layer was separated and dried over anhydrous $\mathrm{Na}_{2} \mathrm{SO}_{4}$, and the EtOAc extract evaporated to dryness under vacuum to yield extract A21 (Figure 7 and Table 3). This procedure generated, after the initial filtering, a solid pretreated wood, which was also extracted first with $\mathrm{CH}_{2} \mathrm{Cl}_{2}$ at room temperature for $24 \mathrm{~h}$ and then with EtOAc under reflux for $2 \mathrm{~h}$ (Figure 7). The $\mathrm{CH}_{2} \mathrm{Cl}_{2}$ extract was discarded, due to its low radical scavenging activity, and the EtOAc extract A22 was kept (Figure 7 and Table 3). Another olive wood sample A (5 g) was pretreated with $40 \mathrm{~mL}$ of $0.5 \mathrm{M} \mathrm{H}_{2} \mathrm{SO}_{4}$ in $\mathrm{H}_{2} \mathrm{O}$ for $3 \mathrm{~h}$ at $130^{\circ} \mathrm{C}$, yielding finally extracts A23 and A24 (Figure 7 and Table 3). Since the hydrolysis pretreatments of olive wood samples were carried out with five different acid conditions and three different times $(1 \mathrm{~h}$, $3 \mathrm{~h}$, and $5 \mathrm{~h}$ ) and each pretreatment yielded two extracts to be investigated, the procedure E7 afforded twenty-four extracts (Figure 7 and Table 3).

The solvent of the extracts obtained in the different procedures was evaporated under vacuum at temperatures not higher than $40^{\circ} \mathrm{C}$. The resulting dry extracts were stored under argon in sealed vials at $-20^{\circ} \mathrm{C}$ until analysis. Extraction yields were calculated as grams of the dry extract per kilogram of olive wood sample.

2.5. DPPH Radical Scavenging Assay. Radical scavenging activity of extracts was determined spectrophotometrically with the stable DPPH radical $[25,26]$. Methanolic solutions $(2.4 \mathrm{~mL})$ of $\mathrm{DPPH}^{*}\left(\sim 7 \times 10^{-5} \mathrm{~mol} \mathrm{~L}^{-1}\right)$ with an absorbance at $515 \mathrm{~nm}$ of $0.80 \pm 0.03 \mathrm{AU}$ were mixed with methanolic solutions $(1.2 \mathrm{~mL})$ of extracts at $50 \mu \mathrm{g} \mathrm{m}^{-1}$ by dissolving the dry extracts in methanol. The experiment was carried out in triplicate. The samples were shaken and kept in the dark for $15 \mathrm{~min}$ at room temperature, and then the decrease of absorbance was measured at $515 \mathrm{~nm}$. Radical scavenging activity of extracts is expressed as radical scavenging percentage (RSP) and was calculated using the following equation [26]:

$$
\operatorname{RSP}(\%)=\left[\frac{A_{B}-A_{A}}{A_{B}}\right] \times 100,
$$

where $A_{B}$ is the absorbance of the blank $(t=0 \mathrm{~min})$ and $A_{A}$ is the absorbance of the tested extract solution $(t=15 \mathrm{~min})$.

2.6. Isolation and Structure Elucidation of Purified Compounds. An aliquot $(73 \mathrm{mg}$ ) of extract D2 (Figure 4 and Table 4) was chromatographed by preparative RP-HPLC (see Section 2.2) to afford compounds $\mathbf{1}$ and 2. Pure compounds $1(21 \mathrm{mg})$ and $2(15 \mathrm{mg})$ were obtained after removing the solvents with a rotary evaporator and the remaining $\mathrm{H}_{2} \mathrm{O}$ with a freeze dryer. The structures of purified compounds 


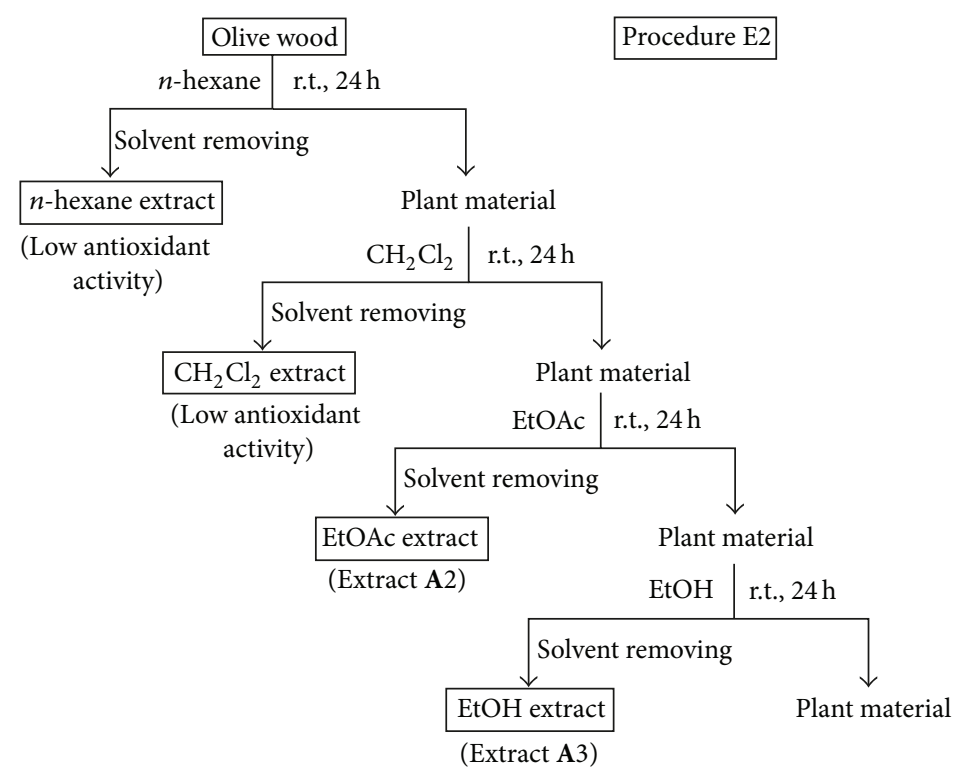

FIGURE 2: Solvent extractions of olive wood sample A following procedure E2.

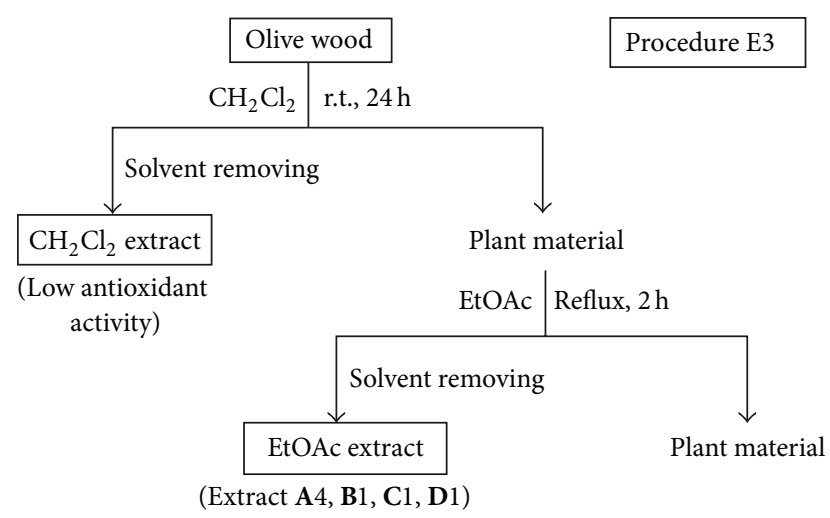

FIGURE 3: Solvent extractions of olive wood samples A, B, C, and D following procedure E3.

were elucidated by various spectroscopic methods and specific optical rotations measurements (see Section 2.2).

$\left(7^{\prime \prime} R\right)-7^{\prime \prime}$-Ethoxyoleuropein (1). Colourless syrup; $[\alpha]_{\mathrm{D}}^{25}-112^{\circ}$ (c 0.10, methanol); UV (methanol) $\lambda_{\max }(\log \varepsilon) 231$ (4.04), $282 \mathrm{~nm}$ (3.36); IR (film) $v_{\max } 3384(\mathrm{OH}), 1705(\mathrm{C}=\mathrm{O})$, $1629(\alpha, \beta$-unsaturated $\mathrm{C}=\mathrm{O}), 1384,1076,1045(\mathrm{C}-\mathrm{O}-\mathrm{C})$ $\mathrm{cm}^{-1}$; ESIMS (positive), $\mathrm{m} / z$ 607.2 $\left([\mathrm{M}+\mathrm{Na}]^{+}\right)$, and 1190.7 $\left([2 \mathrm{M}+\mathrm{Na}]^{+}\right)$, ESIMS (negative), $m / z 583.2\left([\mathrm{M}-\mathrm{H}]^{-}\right) ;$for ${ }^{1} \mathrm{H}$ and ${ }^{13} \mathrm{C}$ NMR data see Table 1.

$\left(7^{\prime \prime} S\right)-7^{\prime \prime}$-Ethoxyoleuropein (2). Colourless syrup; $[\alpha]_{\mathrm{D}}^{25}-95^{\circ}$ (c 0.05, methanol); UV (methanol) $\lambda_{\max }(\log \varepsilon) 231$ (4.17), $282 \mathrm{~nm}$ (3.50); IR (film) $v_{\max } 3385(\mathrm{OH}), 1703(\mathrm{C}=\mathrm{O})$, $1628(\alpha, \beta$-unsaturated $\mathrm{C}=\mathrm{O}), 1384,1076,1045(\mathrm{C}-\mathrm{O}-\mathrm{C})$ $\mathrm{cm}^{-1}$; ESIMS (positive), $\mathrm{m} / z 607.2\left([\mathrm{M}+\mathrm{Na}]^{+}\right)$, and 1190.8 $\left([2 \mathrm{M}+\mathrm{Na}]^{+}\right)$, ESIMS (negative), $m / z 583.3\left([\mathrm{M}-\mathrm{H}]^{-}\right)$; for ${ }^{1} \mathrm{H}$ and ${ }^{13} \mathrm{C}$ NMR data see Table 1.

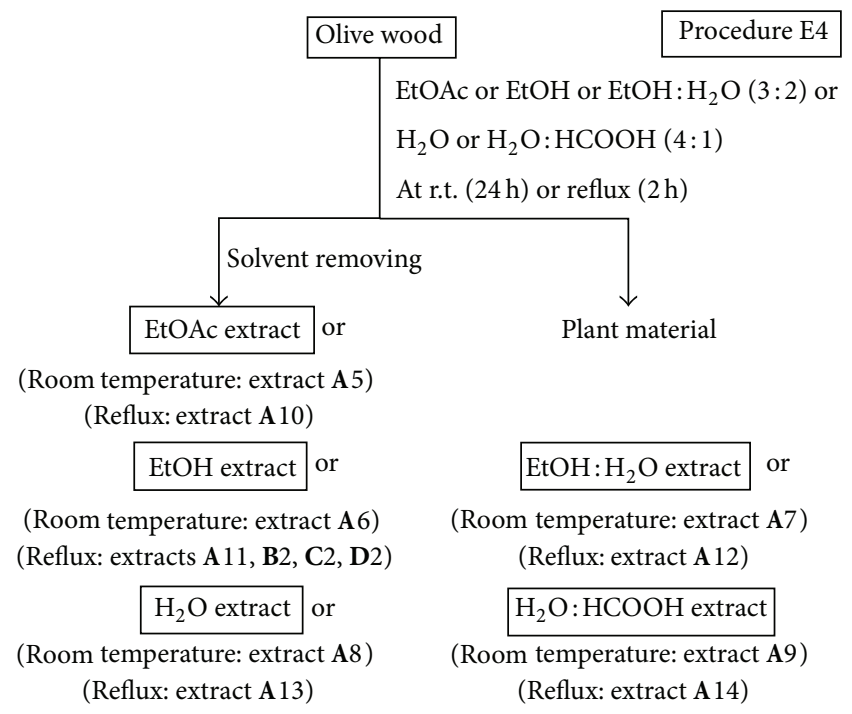

FIGURE 4: Solvent extractions of olive wood samples A, B, C, and D following procedure $\mathrm{E} 4$.

\section{Results and Discussion}

Following up our preliminary results on the radical scavenging activity of dichloromethane and ethanol extracts of olive (O. europaea) wood [20], several extraction procedures using different sequences of solvents with different polarities, at different temperatures and times were investigated in this work. Moreover, the influence of using both (a) acidified solvents (e.g. mixture of water and formic acid) to extract olive wood and (b) acidic hydrolysis pretreatments of the plant material on the yield and antioxidant activity of the resulting extracts was also studied (Figures 1-7). Four samples of olive tree wood, cultivar Picual, have been used to prepare all 
TABLe 1: NMR data (400 MHz, $\left.C_{3} \mathrm{OD}\right)$ of $\left(7^{\prime \prime} R\right)-7^{\prime \prime}$-ethoxyoleuropein (1) and ( $\left.7^{\prime \prime} S\right)-7^{\prime \prime}$-ethoxyoleuropein (2).

\begin{tabular}{|c|c|c|c|c|}
\hline \multirow{2}{*}{ Position } & \multicolumn{2}{|c|}{1} & \multicolumn{2}{|c|}{2} \\
\hline & $\delta_{H}$, mult. $(J$ in $\mathrm{Hz})$ & $\delta_{C}$, mult. & $\delta_{H}$, mult. $(J$ in $\mathrm{Hz})$ & $\delta_{C}$, mult. \\
\hline 1 & $5.92, \mathrm{bs}$ & $95.0, \mathrm{CH}$ & 5.92, bs & 95.1, CH \\
\hline 3 & $7.51, \mathrm{~s}$ & $155.2, \mathrm{CH}$ & $7.52, \mathrm{~s}$ & $155.2, \mathrm{CH}$ \\
\hline 4 & - & 109.3, qC & - & 109.4, qC \\
\hline 5 & 3.99, dd $(4.5,9.0)$ & $31.8, \mathrm{CH}$ & $3.94-4.00, \mathrm{~m}$ & 31.7, CH \\
\hline $6 a$ & $2.72, \mathrm{dd}(4.5,14.2)$ & \multirow{2}{*}{ 41.1, $\mathrm{CH}_{2}$} & $2.72, \mathrm{dd}(4.4,14.4)$ & \multirow{2}{*}{ 41.1, $\mathrm{CH}_{2}$} \\
\hline $6 b$ & 2.47, dd $(9.0,14.2)$ & & 2.47, dd $(9.1,14.4)$ & \\
\hline 7 & - & $173.1, \mathrm{qC}$ & - & 173.0, qC \\
\hline 8 & $6.08, \mathrm{bq}(6.9)$ & $124.9, \mathrm{CH}$ & $6.09, \mathrm{bq}(6.6)$ & 124.9, CH \\
\hline 9 & - & $130.5, \mathrm{qC}$ & - & $130.5, \mathrm{qC}$ \\
\hline 10 & 1.69 bd (6.9) & $13.6, \mathrm{CH}_{3}$ & 1.69, bd $(6.6)$ & 13.6, CH \\
\hline 11 & - & 168.7, qC & - & 168.7, qC \\
\hline $\mathrm{OCH}_{3}$ & $3.71, \mathrm{~s}$ & $51.9, \mathrm{CH}_{3}$ & $3.71, \mathrm{~s}$ & $51.9, \mathrm{CH}_{3}$ \\
\hline $1^{\prime}$ & $4.80, \mathrm{~d}(7.8)$ & $100.8, \mathrm{CH}$ & $4.80, \mathrm{~d}(7.9)$ & $100.8, \mathrm{CH}$ \\
\hline $2^{\prime}$ & $3.34-3.42, \mathrm{~m}$ & $74.8, \mathrm{CH}$ & $3.34-3.44, \mathrm{~m}$ & $74.8, \mathrm{CH}$ \\
\hline $3^{\prime}$ & $3.34-3.42, \mathrm{~m}$ & $77.9, \mathrm{CH}$ & $3.34-3.44, \mathrm{~m}$ & 77.9, $\mathrm{CH}$ \\
\hline $4^{\prime}$ & $3.34-3.42, \mathrm{~m}$ & $71.5, \mathrm{CH}$ & $3.34-3.44, \mathrm{~m}$ & $71.5, \mathrm{CH}$ \\
\hline $5^{\prime}$ & $3.34-3.42, \mathrm{~m}$ & $78.4, \mathrm{CH}$ & $3.34-3.44, \mathrm{~m}$ & 78.4, $\mathrm{CH}$ \\
\hline $6^{\prime} \mathrm{a}$ & 3.89, bd (11.9) & \multirow{2}{*}{ 62.7, $\mathrm{CH}_{2}$} & 3.89, bd (11.8) & \multirow{2}{*}{ 62.7, $\mathrm{CH}_{2}$} \\
\hline $6^{\prime} b$ & 3.67 , dd $(4.9,11.9)$ & & $3.66, \mathrm{dd}(4.9,11.8)$ & \\
\hline $1^{\prime \prime}$ & - & 131.3, qC & - & 131.4, qC \\
\hline $2^{\prime \prime}$ & 6.77, bs & $114.9, \mathrm{CH}$ & 6.77, bs & $114.8, \mathrm{CH}$ \\
\hline $3^{\prime \prime}$ & - & $146.5, \mathrm{qC}$ & - & 146.6, qC \\
\hline $4^{\prime \prime}$ & - & $146.4, \mathrm{qC}$ & - & 146.4, qC \\
\hline $5^{\prime \prime}$ & $6.75, \mathrm{~d}(7.6)$ & $116.3, \mathrm{CH}$ & $6.75, \mathrm{~d}(8.3)$ & $116.3, \mathrm{CH}$ \\
\hline $6^{\prime \prime}$ & 6.65, bd $(7.6)$ & 119.7, CH & 6.65, bd $(8.3)$ & 119.7, CH \\
\hline $7^{\prime \prime}$ & 4.39, dd $(4.1,7.2)$ & $80.7, \mathrm{CH}$ & $4.39, \mathrm{dd}(4.0,7.8)$ & $80.6, \mathrm{CH}$ \\
\hline $8^{\prime \prime} \mathrm{a}$ & $4.02-4.10, \mathrm{~m}$ & \multirow{2}{*}{$69.3, \mathrm{CH}_{2}$} & $4.14, \mathrm{dd}(7.8,11.2)$ & \multirow{2}{*}{$69.2, \mathrm{CH}_{2}$} \\
\hline $8^{\prime \prime} b$ & $4.02-4.10, \mathrm{~m}$ & & $3.94-4.00, \mathrm{~m}$ & \\
\hline $\mathrm{OCH}_{2} \mathrm{CH}_{3}$ & $3.34-3.42, \mathrm{~m}$ & $65.2, \mathrm{CH}_{2}$ & $3.34-3.44, \mathrm{~m}$ & $65.2, \mathrm{CH}_{2}$ \\
\hline $\mathrm{OCH}_{2} \underline{\mathrm{CH}}_{3}$ & $1.15, \mathrm{t}(7.0)$ & $15.6, \mathrm{CH}_{3}$ & $1.15, \mathrm{t}(7.0)$ & $15.6, \mathrm{CH}_{3}$ \\
\hline
\end{tabular}

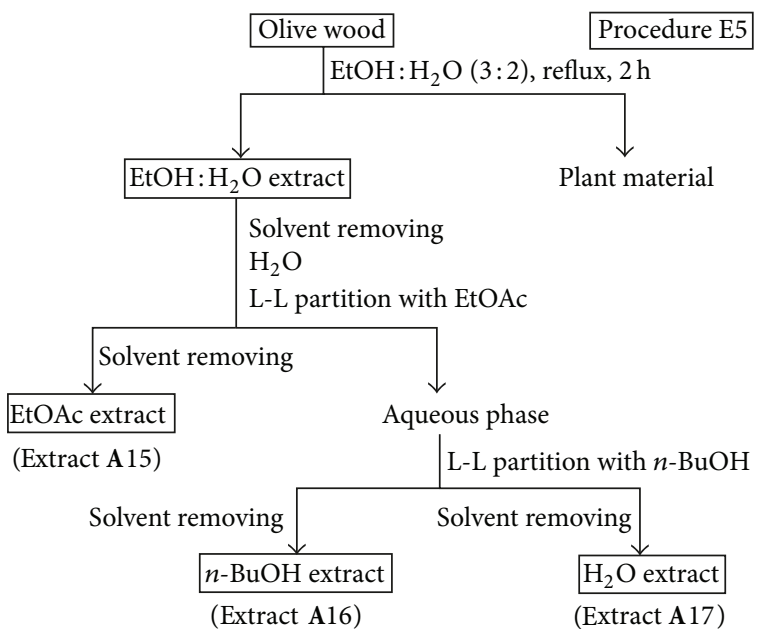

FIgURE 5: Solvent extractions of olive wood sample A following procedure E5. the extracts; three of them were collected in the same olive grove during the pruning period $(\mathbf{A}, \mathbf{B})$ or the harvesting season (D) and the other one in a different olive grove (C). All extracts obtained have been evaluated for their radical scavenging activities, except the hexane and dichloromethane extracts. The two latter ones showed low antioxidant activity in our previous works but allowed the removal of nonpolar components from polar extracts [20,21]. Tables 2-4 show the extraction yields and the DPPH radical scavenging activity of the fifty extracts obtained in this work. The purpose of this work was to find improved extraction conditions to yield olive wood extracts with high antioxidant activities and appropriate extraction yields. The design of every extraction procedure was based on our previous experience and that of others working on optimization of extraction processes, taking into account general considerations on cost, easiness, and suitable scaling-up. Thus, procedure E1 involved a simple sequential extraction with dichloromethane and ethanol at 
TABLE 2: Extraction yields and radical scavenging percentages of several extracts prepared by the extraction procedures E1-E6 from the olive wood sample A.

\begin{tabular}{|c|c|c|c|c|c|}
\hline Extract $^{\mathrm{a}}$ & Procedure $^{\mathrm{b}}$ & Solvent & Temperature & Yield $^{\mathrm{c}}$ & $\mathrm{RSP} \pm \mathrm{SD}^{\mathrm{d}}$ \\
\hline $\mathbf{A} 1$ & E1 & $\mathrm{EtOH}$ & r.t. & 54.1 & $48.8 \pm 0.2$ \\
\hline A2 & E2 & EtOAc & r.t. & 11.0 & $63.2 \pm 0.8$ \\
\hline A3 & E2 & $\mathrm{EtOH}$ & r.t. & 51.4 & $42.1 \pm 0.4$ \\
\hline A4 & E3 & EtOAc & Reflux & 14.2 & $64.9 \pm 0.1$ \\
\hline A5 & $\mathrm{E} 4$ & EtOAc & r.t. & 8.6 & $48.5 \pm 0.8$ \\
\hline A6 & $\mathrm{E} 4$ & $\mathrm{EtOH}$ & r.t. & 40.0 & $42.1 \pm 1.1$ \\
\hline A7 & $\mathrm{E} 4$ & $\mathrm{EtOH}: \mathrm{H}_{2} \mathrm{O} 3: 2$ & r.t. & 111.4 & $27.1 \pm 1.9$ \\
\hline A8 & $\mathrm{E} 4$ & $\mathrm{H}_{2} \mathrm{O}$ & r.t. & 80.0 & $17.1 \pm 1.4$ \\
\hline A9 & $\mathrm{E} 4$ & $\mathrm{H}_{2} \mathrm{O}: \mathrm{HCOOH} 4: 1$ & r.t. & 122.9 & $25.9 \pm 0.5$ \\
\hline A10 & $\mathrm{E} 4$ & EtOAc & Reflux & 11.4 & $50.9 \pm 1.5$ \\
\hline A11 & $\mathrm{E} 4$ & $\mathrm{EtOH}$ & Reflux & 94.3 & $52.4 \pm 1.7$ \\
\hline A12 & $\mathrm{E} 4$ & $\mathrm{EtOH}: \mathrm{H}_{2} \mathrm{O} 3: 2$ & Reflux & 145.7 & $39.6 \pm 1.1$ \\
\hline A13 & $\mathrm{E} 4$ & $\mathrm{H}_{2} \mathrm{O}$ & Reflux & 108.6 & $44.0 \pm 0.2$ \\
\hline A14 & $\mathrm{E} 4$ & $\mathrm{H}_{2} \mathrm{O}: \mathrm{HCOOH} 4: 1$ & Reflux & 211.4 & $33.7 \pm 1.8$ \\
\hline A15 & E5 & EtOAc & Reflux & 22.6 & $54.3 \pm 0.3$ \\
\hline A16 & E5 & $n-\mathrm{BuOH}$ & Reflux & 54.9 & $45.7 \pm 1.3$ \\
\hline A17 & E5 & $\mathrm{H}_{2} \mathrm{O}$ & Reflux & 42.0 & $11.1 \pm 0.8$ \\
\hline A18 & E6 & $\mathrm{Et}_{2} \mathrm{O}$ & Reflux & 4.0 & $48.5 \pm 0.1$ \\
\hline A19 & E6 & $\mathrm{CHCl}_{3}$ & Reflux & 4.0 & $26.1 \pm 0.4$ \\
\hline A 20 & E6 & $n-\mathrm{BuOH}$ & Reflux & 33.7 & $39.6 \pm 0.1$ \\
\hline \multicolumn{3}{|c|}{ Rosemary oleoresin (reference extract) $^{\mathrm{d}}$} & & & $95.0 \pm 0.3$ \\
\hline
\end{tabular}

${ }^{\mathrm{a}}$ Extracts A1-A20 were prepared from the olive wood sample A, collected in April, 2003 (during the pruning period) at the village of Fuensanta, Jaén province, Spain.

${ }^{\mathrm{b}}$ Procedures E1-E6 are detailed in Figures 1-6.

${ }^{c}$ Yield is expressed as grams of extract per kilogram of olive wood sample.

${ }^{\mathrm{d}}$ Radical scavenging percentage (RSP) is expressed as DPPH ${ }^{\bullet}$ scavenging (\%). Values are means of three replicates \pm SD (standard deviation).

${ }^{\mathrm{d}}$ Commercially available rosemary extract was used as reference, at the same concentration $\left(50 \mu \mathrm{g} \mathrm{mL}^{-1}\right)$.

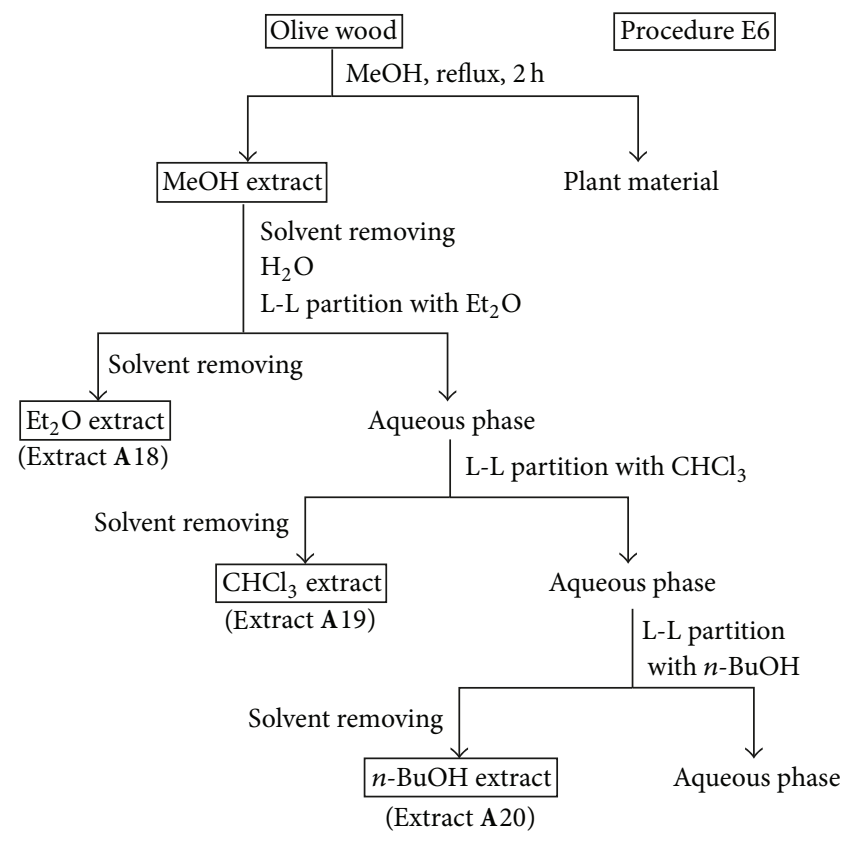

Figure 6: Solvent extractions of olive wood sample A following procedure E6. room temperature (Figure 1). This protocol was used in our preliminary work [20] and allowed us to conclude that ethanol yielded the largest amounts of extracts, with the highest radical scavenging activities. Procedure E2 used the sequence of solvents $n$-hexane, dichloromethane, ethyl acetate, and ethanol at room temperature (Figure 2) in order to perform a better separation of metabolites by groups and choose the better solvent (ethyl acetate or ethanol) to extract antioxidants. As ethyl acetate seemed to be a more selective solvent to extract antioxidants from olive wood, procedure E3 used only two solvents to simplify the protocol (Figure 3): dichloromethane at room temperature to remove nonpolar components, and ethyl acetate under reflux to increase extract yields in active compounds. Procedure E4 involved the direct extraction of olive wood with ethyl acetate at room temperature or under reflux, without previous removal on nonpolar components, and the direct extraction with several more polar solvents, including acidified water (water-formic acid), for comparison purposes (Figure 4). Procedures E5 and E6 involved the initial extraction under reflux of olive wood with aqueous ethanol (Figure 5) and methanol (Figure 6), respectively, followed by several liquid-liquid partitioning with solvents of increasing polarity. These "inverse" procedures were designed to compare results with those of the 
TABLE 3: Extraction yields and radical scavenging percentages of several extracts prepared by the extraction procedure E7 from the olive wood sample $\mathbf{A}$.

\begin{tabular}{|c|c|c|c|c|c|}
\hline Extract $^{\mathrm{a}}$ & Pretreatment $^{\mathrm{b}}$ & Time $^{c}$ & Reextracted material $^{\mathrm{d}}$ & Yield $^{e}$ & $\mathrm{RSP} \pm \mathrm{SD}^{\mathrm{f}}$ \\
\hline A21 & $\mathrm{H}_{2} \mathrm{SO}_{4}$ in $\mathrm{H}_{2} \mathrm{O}$ & $1 \mathrm{~h}$ & Acidic extract & 29.2 & $49.7 \pm 0.6$ \\
\hline A22 & $\mathrm{H}_{2} \mathrm{SO}_{4}$ in $\mathrm{H}_{2} \mathrm{O}$ & $1 \mathrm{~h}$ & Pre-treated wood & 8.8 & $37.4 \pm 0.1$ \\
\hline A23 & $\mathrm{H}_{2} \mathrm{SO}_{4}$ in $\mathrm{H}_{2} \mathrm{O}$ & $3 \mathrm{~h}$ & Acidic extract & 23.6 & $49.6 \pm 0.8$ \\
\hline A24 & $\mathrm{H}_{2} \mathrm{SO}_{4}$ in $\mathrm{H}_{2} \mathrm{O}$ & $3 \mathrm{~h}$ & Pre-treated wood & 4.7 & $59.6 \pm 0.4$ \\
\hline A25 & $\mathrm{H}_{2} \mathrm{SO}_{4}$ in $\mathrm{H}_{2} \mathrm{O}$ & $5 \mathrm{~h}$ & Acidic extract & 34.8 & $49.2 \pm 0.9$ \\
\hline A26 & $\mathrm{H}_{2} \mathrm{SO}_{4}$ in $\mathrm{H}_{2} \mathrm{O}$ & $5 \mathrm{~h}$ & Pre-treated wood & 5.5 & $59.6 \pm 1.6$ \\
\hline A27 & $\mathrm{H}_{2} \mathrm{SO}_{4}$ in $\mathrm{H}_{2} \mathrm{O}: \mathrm{EtOH}$ & $1 \mathrm{~h}$ & Acidic extract & 25.7 & $54.0 \pm 1.3$ \\
\hline A28 & $\mathrm{H}_{2} \mathrm{SO}_{4}$ in $\mathrm{H}_{2} \mathrm{O}: \mathrm{EtOH}$ & $1 \mathrm{~h}$ & Pre-treated wood & 5.2 & $29.9 \pm 1.9$ \\
\hline A29 & $\mathrm{H}_{2} \mathrm{SO}_{4}$ in $\mathrm{H}_{2} \mathrm{O}: \mathrm{EtOH}$ & $3 \mathrm{~h}$ & Acidic extract & 71.2 & $48.1 \pm 2.9$ \\
\hline A30 & $\mathrm{H}_{2} \mathrm{SO}_{4}$ in $\mathrm{H}_{2} \mathrm{O}: \mathrm{EtOH}$ & $3 \mathrm{~h}$ & Pre-treated wood & 5.9 & $38.4 \pm 1.7$ \\
\hline A31 & $\mathrm{H}_{2} \mathrm{SO}_{4}$ in $\mathrm{H}_{2} \mathrm{O}: \mathrm{EtOH}$ & $5 \mathrm{~h}$ & Acidic extract & 74.5 & $45.7 \pm 1.2$ \\
\hline A32 & $\mathrm{H}_{2} \mathrm{SO}_{4}$ in $\mathrm{H}_{2} \mathrm{O}: \mathrm{EtOH}$ & $5 \mathrm{~h}$ & Pre-treated wood & 2.3 & $63.1 \pm 0.6$ \\
\hline A33 & $\mathrm{HCl}$ in $\mathrm{H}_{2} \mathrm{O}$ & $1 \mathrm{~h}$ & Acidic extract & 27.5 & $56.6 \pm 0.5$ \\
\hline A34 & $\mathrm{HCl}$ in $\mathrm{H}_{2} \mathrm{O}$ & $1 \mathrm{~h}$ & Pre-treated wood & 4.9 & $38.1 \pm 0.9$ \\
\hline A35 & $\mathrm{HCl}$ in $\mathrm{H}_{2} \mathrm{O}$ & $3 \mathrm{~h}$ & Acidic extract & 26.4 & $58.5 \pm 2.1$ \\
\hline A36 & $\mathrm{HCl}$ in $\mathrm{H}_{2} \mathrm{O}$ & $3 \mathrm{~h}$ & Pre-treated wood & 6.1 & $68.7 \pm 1.1$ \\
\hline A37 & $\mathrm{HCl}$ in $\mathrm{H}_{2} \mathrm{O}$ & $5 \mathrm{~h}$ & Acidic extract & 23.5 & $48.8 \pm 0.4$ \\
\hline A38 & $\mathrm{HCl}$ in $\mathrm{H}_{2} \mathrm{O}$ & $5 \mathrm{~h}$ & Pre-treated wood & 9.0 & $64.5 \pm 0.4$ \\
\hline A39 & $\mathrm{HCl}$ in $\mathrm{H}_{2} \mathrm{O}: \mathrm{EtOH}$ & $1 \mathrm{~h}$ & Acidic extract & 40.0 & $43.0 \pm 1.2$ \\
\hline A40 & $\mathrm{HCl}$ in $\mathrm{H}_{2} \mathrm{O}: \mathrm{EtOH}$ & $1 \mathrm{~h}$ & Pre-treated wood & 7.5 & $53.8 \pm 0.3$ \\
\hline A41 & $\mathrm{HCl}$ in $\mathrm{H}_{2} \mathrm{O}: \mathrm{EtOH}$ & $3 \mathrm{~h}$ & Acidic extract & 58.5 & $41.6 \pm 0.8$ \\
\hline A 42 & $\mathrm{HCl}$ in $\mathrm{H}_{2} \mathrm{O}: \mathrm{EtOH}$ & $3 \mathrm{~h}$ & Pre-treated wood & 7.1 & $56.4 \pm 1.8$ \\
\hline A43 & $\mathrm{HCl}$ in $\mathrm{H}_{2} \mathrm{O}: \mathrm{EtOH}$ & $5 \mathrm{~h}$ & Acidic extract & 94.1 & $45.9 \pm 2.4$ \\
\hline A 44 & $\mathrm{HCl}$ in $\mathrm{H}_{2} \mathrm{O}: \mathrm{EtOH}$ & $5 \mathrm{~h}$ & Pre-treated wood & 3.6 & $60.9 \pm 1.9$ \\
\hline \multicolumn{3}{|c|}{ Rosemary oleoresin (reference extract) ${ }^{\mathrm{g}}$} & & & $95.0 \pm 0.3$ \\
\hline
\end{tabular}

${ }^{a}$ Extracts A21-A44 were prepared from the olive wood sample A, collected in April, 2003 (during the pruning period) at the village of Fuensanta, Jaén province, Spain.

${ }^{b}$ The olive wood sample A was subjected to a hydrolysis pre-treatment with $0.5 \mathrm{M} \mathrm{H}_{2} \mathrm{SO}_{4}$ in $\mathrm{H}_{2} \mathrm{O}$ (extracts A21-A26), 0.5 M $\mathrm{H}_{2} \mathrm{SO}_{4}$ in $\mathrm{H}_{2} \mathrm{O}$ : EtOH (50:50, $\mathrm{v} / \mathrm{v}$ ) (extracts A27-A32), $1 \mathrm{M} \mathrm{HCl}$ in $\mathrm{H}_{2} \mathrm{O}$ (extracts A33-A38), and $1 \mathrm{M} \mathrm{HCl} \mathrm{in} \mathrm{H}_{2} \mathrm{O}: \mathrm{EtOH}(50: 50$, v/v) (extracts A39-A44) (see Figure 7).

${ }^{\mathrm{C}}$ Time of the hydrolysis pre-treatment on the olive wood sample $\mathbf{A}$ at $130^{\circ} \mathrm{C}$.

${ }^{\mathrm{d}}$ The hydrolysis pre-treatment of olive wood sample $\mathbf{A}$ afforded a liquid acidic extract and a solid pre-treated wood on which further extractions were performed (see Figure 7).

${ }^{\mathrm{e}}$ Yield is expressed as grams of extract per kilogram of olive wood sample.

${ }^{\mathrm{f}}$ Radical scavenging percentage (RSP) is expressed as DPPH ${ }^{*}$ scavenging (\%). Values are means of three replicates \pm SD (standard deviation).

${ }^{\mathrm{g}}$ Commercially available rosemary extract was used as reference, at the same concentration $\left(50 \mu \mathrm{g} \mathrm{mL}^{-1}\right)$.

direct extraction in sequence included in procedures E1, E2, and E3. Finally, procedure E7 (Figure 7) was designed to explore the influence on yield and antioxidant activity of the extracts obtained after an acidic treatment of olive wood (see the following).

3.1. Temperature Effect. The influence of temperature on the extraction was investigated since it affects both the equilibrium and mass transfer rate. Higher temperatures could produce the breakage of bonds between analytes and plant matrix and could thus increase the yield of the extraction [27] or could favour the reaction of compounds like phenols with other plant components, impeding their extraction [1]. Higher temperatures increase the solubility of the compounds, although they may also affect their stability, and chemical transformations may happen; the changes in extract composition usually involve changes in radical scavenging activity. In this study, olive wood shavings from sample $\mathbf{A}$ were subjected to extraction with solvent systems at two temperatures, room temperature, and reflux temperature of each solvent (see Section 2), and as expected, higher yields were obtained under reflux (from 11.4 to $211.4 \mathrm{~g}$ extract $\mathrm{kg}^{-1}$ wood) than at room temperature (from 8.6 to $122.9 \mathrm{~g}$ extract $\mathrm{kg}^{-1}$ wood) (Table 2). For instance, the increase of the yield of extracts obtained under reflux with respect to those obtained at room temperature is considerable; from a $30 \%$ (extract A4 versus extract A2) up to a 136\% (extract A11 versus extract $\mathbf{A} 6$ ). In contrast, the increases observed for the radical scavenging percentage (RSP) of the same extracts are comparatively lower: from a 3\% (extract A4 versus extract A2) up to a 24\% (extract A11 versus extract A6). In general, it can be said that extract yields reach a considerable increase with the temperature while RSP values increase moderately. Indeed, the highest value for radical scavenging activity at 
TABLE 4: Extraction yields and radical scavenging percentages of several extracts prepared by the extraction procedures E3 and E4 from olive wood samples A, B, C, and $\mathbf{D}$.

\begin{tabular}{|c|c|c|c|c|c|}
\hline Olive wood sample $^{\mathrm{a}}$ & Extract $^{\mathrm{a}}$ & Procedure $^{\mathrm{b}}$ & Solvent & Yield $^{c}$ & $\mathrm{RSP} \pm \mathrm{SD}^{\mathrm{d}}$ \\
\hline A & A4 & E3 & EtOAc & 14.2 & $64.9 \pm 0.1$ \\
\hline B & B1 & E3 & EtOAc & 46.8 & $63.7 \pm 1.3$ \\
\hline $\mathrm{C}$ & $\mathrm{Cl}$ & E3 & EtOAc & 91.8 & $59.1 \pm 2.6$ \\
\hline D & D1 & E3 & EtOAc & 14.2 & $40.5 \pm 0.7$ \\
\hline A & A11 & E4 & $\mathrm{EtOH}$ & 94.3 & $52.4 \pm 1.7$ \\
\hline B & B2 & E4 & $\mathrm{EtOH}$ & 117.3 & $38.3 \pm 2.6$ \\
\hline $\mathrm{C}$ & $\mathrm{C} 2$ & E4 & $\mathrm{EtOH}$ & 172.5 & $42.4 \pm 0.6$ \\
\hline D & D2 & E4 & $\mathrm{EtOH}$ & 81.7 & $42.9 \pm 2.2$ \\
\hline \multicolumn{5}{|c|}{ Rosemary oleoresin (reference extract) ${ }^{\mathrm{e}}$} & $95.0 \pm 0.3$ \\
\hline
\end{tabular}

${ }^{a}$ Extracts were prepared from (a) the olive wood sample A, collected in April, 2003 (during the pruning period) at the village of Fuensanta, Jaén province, Spain; (b) the olive wood sample B, collected in March, 2005 (during the pruning period) at the same location of sample A; (c) the olive wood sample C, collected in March, 2005 (during the pruning period) at the village of Mogón, Jaén province, Spain; (d) the olive wood sample D, collected in November, 2006 (during the harvesting season) at the same location of sample $\mathbf{A}$.

${ }^{\mathrm{b}}$ Procedures E3 and E4 are detailed in Figures 3 and 4.

${ }^{c}$ Yield is expressed as grams of extract per kilogram of olive wood sample.

${ }^{\mathrm{d}}$ Radical scavenging percentage (RSP) is expressed as DPPH ${ }^{*}$ scavenging (\%). Values are means of three replicates \pm SD (standard deviation).

${ }^{\mathrm{e}}$ Commercially available rosemary extract was used as reference, at the same concentration $\left(50 \mu \mathrm{g} \mathrm{mL} \mathrm{m}^{-1}\right)$.

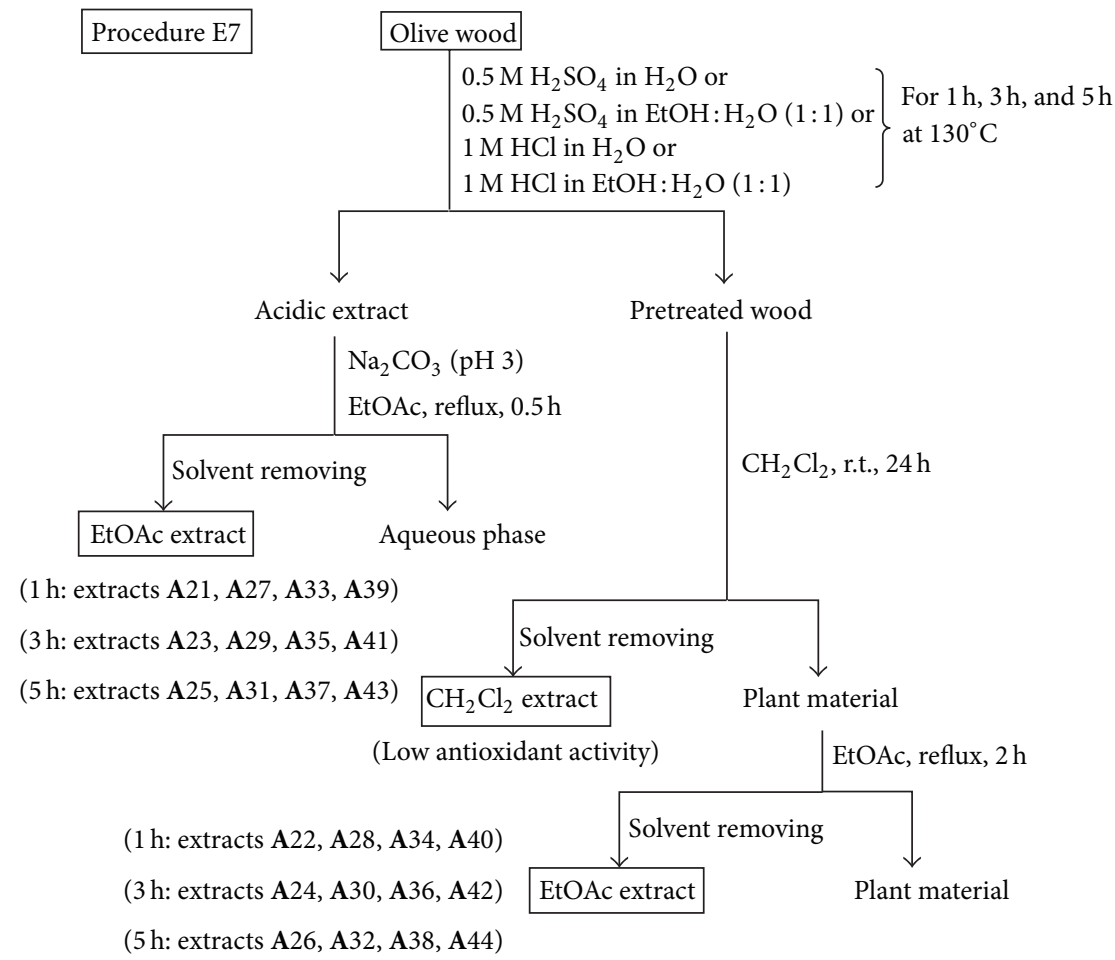

FIGURE 7: Hydrolysis pretreatment and solvent extractions of olive wood sample A following procedure E7.

room temperature (63.2\%, extract A2) was similar to the highest one for extractions under reflux (64.9\%, extract A4) (Table 2). This means that the extraction protocols using refluxing solvents are not necessarily better than those using solvents at room temperature.

3.2. Solvent Composition. Since the radical scavenging activity depends on the extract composition, comparative studies for selecting the optimal solvents providing maximum antioxidant activity are required for each plant material. Methanol, mixtures of ethanol (or methanol) and water, ethyl acetate, and diethyl ether have been the most common extraction solvents reported in the literature for the extraction of phenols from wood samples [28]. Considering our previous work on olive wood extracts [20-22], where nonoptimized extraction protocols were used, a more comprehensive study of the extraction yields and radical scavenging activities of olive wood extracts obtained from sample $\mathbf{A}$ with different 
neat solvents or mixtures of them was carried out in this work (Figures 1-6). The results are shown in Table 2. Hexane, dichloromethane, ethyl acetate, and ethanol were chosen as solvents to extract olive tree wood shavings in three different manners (procedures E1, E2, and E3). The ethyl acetate extract obtained under reflux of an olive wood sample (A4), previously extracted with dichloromethane at room temperature, afforded the best radical scavenging activity (64.9\%). Ethyl acetate, ethanol, ethanol-water, water, and water-formic acid mixtures have also been used for each extraction of a fresh and non previously extracted olive tree wood sample, following procedure E4 (Figure 4). Ethanolic and aqueous extracts yields were around 6-fold and 9-fold higher than those of ethyl acetate extracts, respectively (Table 2). It is documented that an addition of water to solvents causes swelling of the plant material, thereby allowing the solvent to penetrate the solid matrix more easily, which leads to higher yields [27]. However, the radical scavenging percentages of ethanolic and aqueous extracts were up to 3-fold lower than those of ethyl acetate extracts. Moreover, a $\mathrm{pH}$ effect on the extraction yield has also been reported [1]. To study the $\mathrm{pH}$ influence, two additional extracts obtained with a water-formic acid mixture have also been evaluated in this work (extracts A9 and A14). The yields of these extracts were higher than those of aqueous extracts without acid (extracts A8 and A13), but there were no significant changes in their radical scavenging percentages. Two other extraction procedures (E5 and E6) have been checked according to those described in the literature $[29,30]$. In both procedures, an aqueous ethanolic extract (procedure E5, Figure 5) and a methanolic extract (procedure E6, Figure 6) were partitioned using successively ethyl acetate and $n$-butanol (procedure E5) and diethyl ether, chloroform, and $n$-butanol (procedure E6) as solvents. The yields of alcoholic (extracts A16 and A20) and aqueous extracts (extract A17) were the highest ones, and the ethyl acetate extract (extract A15) was the most active one again. Thus, ethyl acetate extracts from olive wood, obtained either through direct extraction (A4) or by successive liquid-liquid partitioning (A15) procedures, are the most active ones. This solvent has been used on other occasions to separate low molecular weight polyphenols from other wood sources [31, 32].

3.3. Acid Hydrolysis Pretreatment Effect on Wood Shavings. It is known that during the conversion of hemicellulose into sugar and sugar oligomers by mild hydrolysis of lignocellulosic materials, cell wall-linked phenolic compounds are also solubilized [12]. A number of technologies are available for the hydrolysis of these materials. The autohydrolysis is the simplest one, where the lignocellulosic material is contacted with water or steam $[3,33]$. In hardwoods, acid hydrolysis processes have been extensively studied as well as the effect of the operational conditions on the yield and the antioxidant activity of the phenolic fraction recovered [3]. Solvent extraction with ethyl acetate has successfully been applied for purification or refining purposes, since saccharides remain in the aqueous phase, whereas the nonsaccharide compounds (part of them, of phenolic nature) are transferred to the organic phase. To evaluate the effect of this pretreatment on olive wood samples, several experiments were designed based on the literature using sulfuric acid $[34,35]$ or hydrochloric acid [36]. In this work, after acidic hydrolysis pretreatment of olive wood shavings, the filtration and extraction of both liquid and solid phases were carried out using procedure E7 (Figure 7). Table 3 shows the extraction yields and the DPPH radical scavenging activity of the ethyl acetate extracts obtained according to this procedure. Yields of the ethyl acetate extracts obtained from the liquid phase of procedure E7 ("acidic extract" in Figure 7) by partitioning against ethyl acetate (extracts A21, A23, A25, A27, A29, A31, A33, A35, A37, A39, A41, A43) were up to 10-fold higher than those of ethyl acetate extracts obtained following a consecutive extraction of the solid phase of procedure E7 ("pretreated wood" in Figure 7) with dichloromethane and ethyl acetate (extracts A22, A24, A26, A28, A30, A32, A34, A36, A38, A40, A42, and A44) (Table 3). However, among the radical scavenging percentage data of the latter extracts (from 29.9 to $68.7 \%$ ), the best result (extract A36, 68.7\%) was only 10\% higher than the highest one (extract A35, 58.5\%) of the former ones (from 41.6 to $58.5 \%$ ). Besides, it can be said that there are no important differences between the radical scavenging activities obtained with the acidic pretreatment of olive wood using sulfuric acid (63.1\% is the highest radical scavenging value; extract A32) or hydrochloric acid (68.7\% is the highest one; extract A36), neither in aqueous-alcoholic solutions nor in aqueous solutions. In terms of pretreatment time, the radical scavenging activity was in general higher after 3 or $5 \mathrm{~h}$ than after $1 \mathrm{~h}$. In conclusion, the best radical scavenging activities were those corresponding to extracts A36 and A38, obtained from the ethyl acetate extraction of the pretreated olive wood shavings with $1 \mathrm{M} \mathrm{HCl}$ after $3 \mathrm{~h}$ and $5 \mathrm{~h}$, whose radical scavenging percentages were $68.7 \%$ and $64.5 \%$, respectively. These results were similar to that obtained for extract A4 (64.9\% of radical scavenging activity), which was prepared by extraction with ethyl acetate under reflux of the same wood sample A previously extracted with dichloromethane according to procedure E3 (Figure 3 and Table 2). However, if yield values are compared, it can be said that the acid hydrolysis pretreatment of olive wood does not improve the simplest and cheapest procedure E3, since extract A4 was obtained with a $14.2 \%$ yield while extracts A36 and A38 were obtained with $6.1 \%$ and $9.0 \%$ yields, respectively.

3.4. Location and Season Collection Data. The geographic origin, as well as climatic condition, harvesting date, storage, environmental, and technological factors, affects the composition of plant material samples and consequently their antioxidant activities [1, 24, 37]. Four different woods collected at two different locations and seasons have been studied (samples A, B, C, and D; see Section 2 for details). Taking into consideration the best results previously found for sample A, procedure E3 was chosen as the extraction protocol for extracting the other three samples. Later, these samples were also extracted by procedure E4 (with EtOH under reflux), which also showed good behaviour with sample A. Yields of the ethyl acetate extracts (procedure E3) ranged from $14.2 \mathrm{~g}$ extract $\mathrm{kg}^{-1}$ wood for $\mathbf{A}$ to $91.8 \mathrm{~g}$ extract $\mathrm{kg}^{-1}$ wood for $\mathrm{C}$, and the yields of the ethanol ones (procedure E4) from $81.7 \mathrm{~g}$ extract $\mathrm{kg}^{-1}$ wood for $\mathbf{D}$ to $172.5 \mathrm{~g}$ 


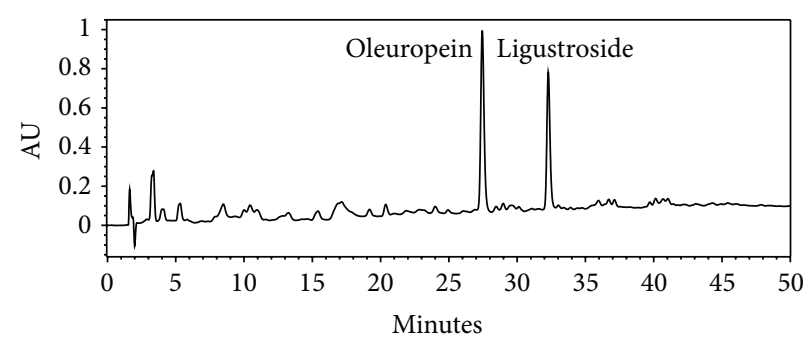

(a)

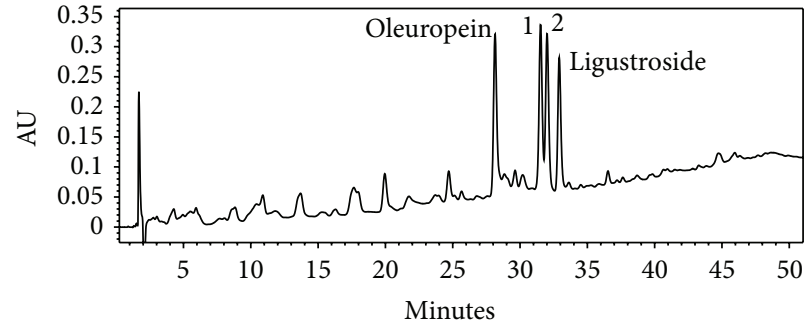

(b)

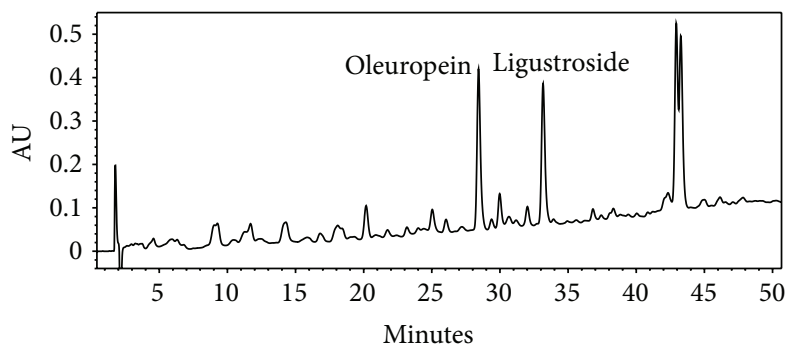

(c)

Figure 8: HPLC profiles of olive wood extracts at $230 \mathrm{~nm}$ : (a) ethyl acetate extract A4, (b) ethanol extract D2, and (c) direct $n$-butanol extract from olive wood sample $\mathbf{D}$.

extract $\mathrm{kg}^{-1}$ wood for $\mathbf{C}$ (Table 4 ). Hence, yields of the ethyl acetate extracts were lower than those of the ethanol ones which is in agreement with previous results obtained for sample A. However, some differences in antioxidant activity and composition have been found among the four olive wood samples studied; regarding the radical scavenging activity, the ethyl acetate extract of the sample collected during the olives' harvesting season (sample D) showed a slightly lower radical scavenging percentage than that of the ethanol extract, which is in contrast with the results obtained for sample $\mathbf{A}$. The HPLC-DAD-MS analyses of seven of these eight extracts (both ethyl acetate and ethanol extracts) showed similar chromatographic profiles (Figure 8(a)), where oleuropein and ligustroside were the main components as described before by us for other olive wood samples [21, 22]. However, the chromatogram of the ethanolic extract from the sample collected during the olives' harvesting season (extract D2) showed four major peaks: oleuropein, ligustroside, and two compounds not identified previously by us (Figure 8(b)).

3.5. Structure Elucidation of the Unidentified Compounds. An aliquot of the ethanolic extract from the sample collected in autumn (extract D2) was submitted to further preparative RP-HPLC separations, and two pure secoiridoids, compounds 1 and 2, were therefore isolated (Figure 9). Compounds 1 and 2 were characterized by UV, IR, MS, ${ }^{1} \mathrm{H}$ NMR, ${ }^{13} \mathrm{C}$ NMR, 2D NMR, and specific optical rotation measurements. These spectroscopic data indicate that compounds $\mathbf{1}$ and 2 were two stereoisomers of $7^{\prime \prime}$-ethoxyoleuropein. The spectral data of $\mathbf{1}$ are in agreement with earlier published data for lucidumoside $\mathrm{C}$, which was isolated for the first time from an ethanolic extract of Ligustrum lucidum fruit [38]. However, the exact configuration at C- $7^{\prime \prime}$ was not given in that paper. In order to establish the stereochemistry at C- $7^{\prime \prime}$ of $\mathbf{1}$ and 2 , a comparative study of the NMR spectra of both compounds with those of $\left(7^{\prime \prime} R\right)$ - and $\left(7^{\prime \prime} S\right)-7^{\prime \prime}$-methoxyoleuropein was carried out. These methoxyoleuropein derivatives were isolated for the first time from the methanolic extract of Jasminun officinale L. var. grandiflorum leaves and stems [39]. The $7^{\prime \prime} R$-epimer has signals for $\mathrm{H}-8^{\prime \prime} \mathrm{a}$ and $\mathrm{H}-8^{\prime \prime} \mathrm{b}$ differing by $0.06 \mathrm{ppm}$ while in the $7^{\prime \prime} \mathrm{S}$-epimer the signals for $\mathrm{H}-8^{\prime \prime} \mathrm{a}$ and $\mathrm{H}-8^{\prime \prime} \mathrm{b}$ differ by $0.20 \mathrm{ppm}$. Since compounds 1 and 2 showed $\Delta \delta$ values of 0.03 and 0.17 , respectively, the stereochemistry at carbon C- $7^{\prime \prime}$ for $\mathbf{1}$ is assigned as $7^{\prime \prime} R$ and for 2 as $7^{\prime \prime} S$. Both diastereoisomers of $7^{\prime \prime}$-ethoxyoleuropein seem to be artefacts of $7^{\prime \prime}$-hydroxyoleuropein produced by the extraction with ethanol. In order to prove this hypothesis, the same olive wood sample $\mathbf{D}$ was extracted following the same extraction procedure (procedure E4; $2 \mathrm{~h}$ at reflux) with acetone, in one case, and with $n$-butanol in the other case. The corresponding acetone and $n$-butanol extracts were analysed by HPLC-DAD-MS and only the second extracts presented two new peaks with an $[\mathrm{M}-\mathrm{H}]^{-}$ion at $m / z 611.2$ for the two diastereoisomers. These were assigned as the corresponding artefacts produced by $n$-butanol (Figure $8(c)$ ), although no further efforts were made to isolate them. It is well documented that olive drupes contain a hydroxylated oleuropein derivative, with a hydroxyl group at the elenoic moiety, known as 10-hydroxyoleuropein [40]. However, the presence of $7^{\prime \prime}$-hydroxyoleuropein, with the hydroxyl group located at the phenylethanolic moiety, has only been detected in some occasion in olive drupes [41]. Recently, we reported the presence of $\left(7^{\prime \prime} S\right)-7^{\prime \prime}$-hydroxyoleuropein in olive wood [22]. This molecule, never found previously in O. europaea, is a secondary metabolite in other genera of the Oleaceae family, such as Fraxinus and Ligustrum [42]. It is known that a hydroxyl group located at a benzylic position, such as in the case of $7^{\prime \prime}$-hydroxyoleuropein, is endowed with 


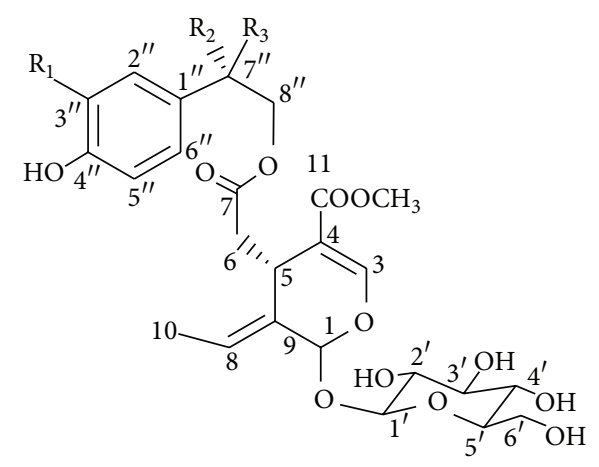

\begin{tabular}{|llll|}
\hline Oleuropein & $\mathrm{R}_{1}=\mathrm{OH} ;$ & $\mathrm{R}_{2}=\mathrm{H} ;$ & $\mathrm{R}_{3}=\mathrm{H}$ \\
\hline Ligustroside & $\mathrm{R}_{1}=\mathrm{H} ;$ & $\mathrm{R}_{2}=\mathrm{H} ;$ & $\mathrm{R}_{3}=\mathrm{H}$ \\
\hline$\left(7^{\prime \prime} R\right)-7^{\prime \prime}$-Ethoxyoleuropein $(\mathbf{1})$ & $\mathrm{R}_{1}=\mathrm{OH} ;$ & $\mathrm{R}_{2}=\mathrm{H} ;$ & $\mathrm{R}_{3}=\mathrm{OCH}_{2} \mathrm{CH}_{3}$ \\
\hline$\left(7^{\prime \prime} S\right)-7^{\prime \prime}$-Ethoxyoleuropein $(2)$ & $\mathrm{R}_{1}=\mathrm{OH} ;$ & $\mathrm{R}_{2}=\mathrm{OCH}_{2} \mathrm{CH}_{3} ; \mathrm{R}_{3}=\mathrm{H}$ \\
\hline
\end{tabular}

FIGURE 9: Structures of the isolated compounds from the olive wood sample D.

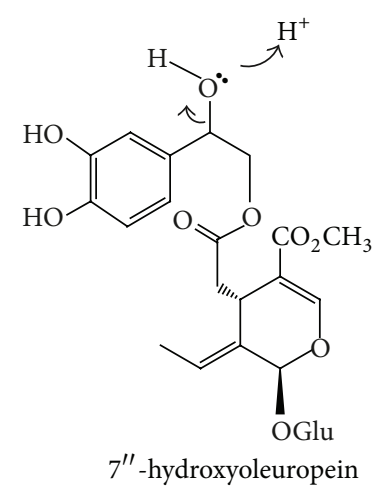

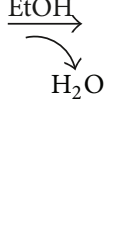

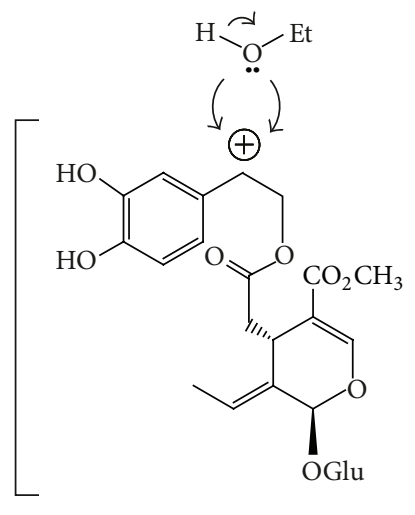

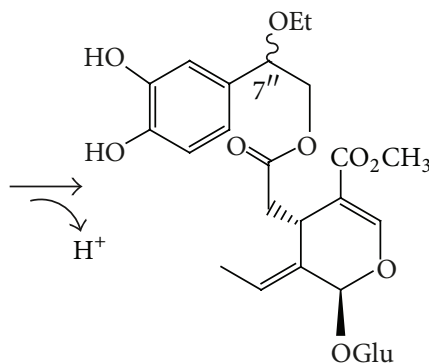

Compound $\mathbf{1}\left(7^{\prime \prime} R\right)$ Compound $2\left(7^{\prime \prime} S\right)$

Scheme 1: Proposed reaction pathway for the conversion of the natural product $7^{\prime \prime}$-hydroxyoleuropein into the artefacts $\mathbf{1}$ and $\mathbf{2}$ during the extraction of olive wood (sample D) with ethanol.

a special reactivity. Indeed, the acid-catalysed synthesis of ethers from benzylic alcohols and aliphatic alcohols has been described [43]. Thus, we can postulate that when the olive wood extracts were prepared under reflux with ethanol as solvent, a catalytical substitution of the hydroxyl group of $7^{\prime \prime}$ hydroxyoleuropein took place, yielding the related $7^{\prime \prime}$-ethoxyoleuropein derivatives (Scheme 1).

\section{Conclusions}

Fifty extracts of olive (Olea europaea L., cultivar Picual) wood have been prepared following seven different solvent extraction protocols in order to find the best conditions to optimize yield and radical scavenging activity. It was observed that the yields of the ethanolic, aqueous, and acid-aqueous extracts were higher than those of the ethyl acetate extracts, while the opposite was observed for the antioxidant activity. Indeed, the most active extracts were obtained with ethyl acetate either through direct extraction or by successive liquid-liquid partitioning procedures. When the extracts were obtained under reflux, the yields were higher than at room temperature, although the radical scavenging activities were similar. There are no significant differences between the results obtained from the pretreatment of olive wood with sulfuric acid or hydrochloric acid, neither in aqueous-alcoholic solutions nor in aqueous solutions. Pretreatment times of 3 and $5 \mathrm{~h}$ gave higher radical scavenging activities than those of $1 \mathrm{~h}$. The best result for the hydrolysis pretreatments (with yields of $9.0 \mathrm{~g}$ extract $\mathrm{kg}^{-1}$ wood and radical scavenging percentages of $68.7 \%$ ) was similar to that obtained for ethyl acetate extractions without pretreatment (from 8.6 to $14.2 \mathrm{~g}$ extract $\mathrm{kg}^{-1}$ wood for yield and from 48.5 to $64.9 \%$ for radical scavenging activity). Significant differences were observed for the extraction yields and radical scavenging activity from those olive wood samples collected at two different geographical origins, years, and seasons. The HPLC-DAD-MS analysis of the ethyl acetate and ethanol extracts showed similar profiles, where oleuropein and ligustroside were the main components. However, the chromatogram of the ethanolic extract from the sample collected during the olives' harvesting season (extract 
D2) showed four major peaks: oleuropein, ligustroside, and two compounds identified as $\left(7^{\prime \prime} R\right)-7^{\prime \prime}$-ethoxyoleuropein (1) and $\left(7^{\prime \prime} S\right)-7^{\prime \prime}$-ethoxyoleuropein (2). Compounds 1 and 2 were shown to be artefacts formed from the natural product $7^{\prime \prime}$-hydroxyoleuropein during the extraction process with ethanol.

\section{Acknowledgments}

The authors wish to thank the Spanish Ministerio de Educación y Ciencia for financial support $(\mathrm{R}+\mathrm{D}$ Project CTQ2005-07005/PPQ; partial financial support from the FEDER funds of the European Union) and the Andalusian Government, Junta de Andalucía, for a predoctoral fellowship to M. Pérez-Bonilla. They are grateful to Dr. P. de Waard for his technical assistance in recording NMR spectra and also to the Centro de Instrumentación Cientifico-Técnica of the University of Jaén for the financial support.

\section{References}

[1] A. Moure, J. M. Cruz, D. Franco et al., "Natural antioxidants from residual sources," Food Chemistry, vol. 72, no. 2, pp. 145171, 2001.

[2] F. Visioli and C. Galli, "Olives and their production waste products as sources of bioactive compounds," Current Topics in Nutraceutical Research, vol. 1, no. 1, pp. 85-88, 2003.

[3] G. Garrote, J. M. Cruz, A. Moure, H. Domínguez, and J. C. Parajó, "Antioxidant activity of byproducts from the hydrolytic processing of selected lignocellulosic materials," Trends in Food Science and Technology, vol. 15, no. 3-4, pp. 191-200, 2004.

[4] N. Balasundram, K. Sundram, and S. Samman, "Phenolic compounds in plants and agri-industrial by-products: antioxidant activity, occurrence, and potential uses," Food Chemistry, vol. 99, no. 1, pp. 191-203, 2006.

[5] R. Carle, P. Keller, A. Schieber et al., "Method for obtaining useful materials from the by-products of fruit and vegetable processing," WO Patent 2001078859, 2001.

[6] J. L. Torres, B. Varela, M. T. García et al., "Valorization of grape (Vitis vinifera) byproducts. Antioxidant and biological properties of polyphenolic fractions differing in procyanidin composition and flavonol content," Journal of Agricultural and Food Chemistry, vol. 50, no. 26, pp. 7548-7555, 2002.

[7] W. Peschel, F. Sánchez-Rabaneda, W. Diekmann et al., "An industrial approach in the search of natural antioxidants from vegetable and fruit wastes," Food Chemistry, vol. 97, no. 1, pp. 137-150, 2006.

[8] S. Savatovic, G. Cetkovic, J. Canadanovic-Brunet, and S. Djilas, "Tomato waste: a potential source of hydrophilic antioxidants," International Journal of Food Sciences and Nutrition, vol. 63, no. 2, pp. 129-137, 2012.

[9] V. Papadimitriou, G. A. Maridakis, T. G. Sotiroudis, and A. Xenakis, "Antioxidant activity of polar extracts from olive oil and olive mill wastewaters: an EPR and photometric study," European Journal of Lipid Science and Technology, vol. 107, no. 7-8, pp. 513-520, 2005.

[10] F. Visioli, A. Romani, N. Mulinacci et al., "Antioxidant and other biological activities of olive mill waste waters," Journal of Agricultural and Food Chemistry, vol. 47, no. 8, pp. 3397-3401, 1999.

[11] O. Benavente-García, J. Castillo, J. Lorente, A. Ortuño, and J. A. del Río, "Antioxidant activity of phenolics extracted from Olea europaea L. leaves," Food Chemistry, vol. 68, no. 4, pp. 457-462, 2000.

[12] B. Felizón, J. Fernández-Bolaños, A. Heredia, and R. Guillén, "Steam explosion pretreatment of olive cake," Journal of the American Oil Chemists Society, vol. 77, no. 1, pp. 15-22, 2000.

[13] H. Domínguez, J. Torres, and M. J. Núñez, "Antioxidant phenolics as food additives from agricultural wastes," Polyphénols Actualités, vol. 21, pp. 25-30, 2001.

[14] B. Amro, T. Aburjai, and S. Al-Khalil, "Antioxidative and radical scavenging effects of olive cake extract," Fitoterapia, vol. 73, no. 6, pp. 456-461, 2002.

[15] A. Ranalli, L. Lucera, and S. Contento, "Antioxidizing potency of phenol compounds in olive mill wastewater," Journal of Agricultural and Food Chemistry, vol. 51, no. 26, pp. 7636-7641, 2003.

[16] H. K. Obied, M. S. Allen, D. R. Bedgood, P. D. Prenzler, K. Robards, and R. Stockmann, "Bioactivity and analysis of biophenols recovered from olive mill waste," Journal of Agricultural and Food Chemistry, vol. 53, no. 4, pp. 823-837, 2005.

[17] G. Rodríguez, R. Rodríguez, J. Fernández-Bolaños, R. Guillén, and A. Jiménez, "Antioxidant activity of effluents during the purification of hydroxytyrosol and 3,4-dihydroxyphenylglycol from olive oil waste," European Food Research and Technology, vol. 224, no. 6, pp. 733-741, 2007.

[18] G. Rodríguez, A. Lama, M. Trujillo, J. L. Espartero, and J. Fernández-Bolaños, "Isolation of powerful antioxidant from Olea europaea fruit-mill waste: 3,4-dihydroxyphenylglycol," Food Science and Technology, vol. 42, no. 2, pp. 483-490, 2009.

[19] I. González-Hidalgo, S. Bañón, and J. M. Ros, "Evaluation of table olive by-product as a source of natural antioxidants," International Journal of Food Science and Technology, vol. 47, no. 4, pp. 674-681, 2012.

[20] J. Altarejos, S. Salido, M. Pérez-Bonilla et al., "Preliminary assay on the radical scavenging activity of olive wood extracts," Fitoterapia, vol. 76, no. 3-4, pp. 348-351, 2005.

[21] M. Pérez-Bonilla, S. Salido, T. A. van Beek et al., "Isolation and identification of radical scavengers in olive tree (Olea europaea) wood," Journal of Chromatography A, vol. 1112, no. 1-2, pp. 311318, 2006.

[22] M. Pérez-Bonilla, S. Salido, T. A. van Beek et al., "Isolation of antioxidative secoiridoids from olive wood (Olea europaea L.) guided by on-line HPLC-DAD-radical scavenging detection," Food Chemistry, vol. 124, no. 1, pp. 36-41, 2011.

[23] H. Zbidi, S. Salido, J. Altarejos et al., "Olive tree wood phenolic compounds with human platelet antiaggregant properties," Blood Cells, Molecules, and Diseases, vol. 42, no. 3, pp. 279-285, 2009.

[24] G. Beltrán, C. del Río, S. Sánchez, and L. Martínez, "Seasonal changes in olive fruit characteristics and oil accumulation during ripening process," Journal of the Science of Food and Agriculture, vol. 84, no. 13, pp. 1783-1790, 2004.

[25] W. Brand-Williams, M. E. Cuvelier, and C. Berset, "Use of a free radical method to evaluate antioxidant activity," Food Science and Technology, vol. 28, no. 1, pp. 25-30, 1995.

[26] A. von Gadow, E. Joubert, and C. F. Hansmann, "Comparison of the antioxidant activity of aspalathin with that of other plant phenols of rooibos tea (Aspalathus linearis), $\alpha$-tocopherol, BHT, and BHA," Journal of Agricultural and Food Chemistry, vol. 45, no. 3, pp. 632-638, 1997.

[27] S. Mukhopadhyay, D. L. Luthria, and R. J. Robbins, "Optimization of extraction process for phenolic acids from black cohosh (Cimicifuga racemosa) by pressurized liquid extraction," Journal 
of the Science of Food and Agriculture, vol. 86, no. 1, pp. 156-162, 2006.

[28] B. F. de Simón, E. Cadahía, E. Conde, and M. C. GarcíaVallejo, "Low molecular weight phenolic compounds in Spanish oakwoods," Journal of Agricultural and Food Chemistry, vol. 44, no. 6, pp. 1507-1511, 1996.

[29] H. Tsukamoto, S. Hisada, and S. Nishibe, "Lignans from bark of the Olea plants. I," Chemical and Pharmaceutical Bulletin, vol. 32, no. 7, pp. 2730-2735, 1984.

[30] I. Parejo, F. Viladomat, J. Bastida et al., "Comparison between the radical scavenging activity and antioxidant activity of six distilled and nondistilled mediterranean herbs and aromatic plants," Journal of Agricultural and Food Chemistry, vol. 50, no. 23, pp. 6882-6890, 2002.

[31] J. M. Cruz, J. M. Domínguez, H. Domínguez, and J. C. Parajó, "Antioxidant and antimicrobial effects of extracts from hydrolysates of lignocellulosic materials," Journal of Agricultural and Food Chemistry, vol. 49, no. 5, pp. 2459-2464, 2001.

[32] A. Moure, H. Domínguez, and J. C. Parajó, "Antioxidant activity of liquors from aqueous treatment of Pinus radiata wood," Wood Science and Technology, vol. 39, no. 2, pp. 129-139, 2005.

[33] J. M. Cruz, H. Domínguez, and J. C. Parajó, "Anti-oxidant activity of isolates from acid hydrolysates of Eucalyptus globulus wood," Food Chemistry, vol. 90, no. 4, pp. 503-511, 2005.

[34] J. Fernández-Bolaños, B. Felizón, M. Brenes, R. Guillén, and A. Heredia, "Hydroxytyrosol and tyrosol as the main compounds found in the phenolic fraction of steam-exploded olive stones," Journal of the American Oil Chemists Society, vol. 75, no. 11, pp. 1643-1649, 1998.

[35] I. Romero, E. Ruiz, E. Castro, and M. Moya, "Acid hydrolysis of olive tree biomass," Chemical Engineering Research and Design, vol. 88, no. 5-6, pp. 633-640, 2010.

[36] M. Bouaziz and S. Sayadi, "Isolation and evaluation of antioxidants from leaves of a Tunisian cultivar olive tree," European Journal of Lipid Science and Technology, vol. 107, no. 7-8, pp. 497$504,2005$.

[37] M. M. Torres, P. Pierantozzi, M. E. Cáceres, P. Labombarda, G. Fontanazza, and D. M. Maestri, "Genetic and chemical assessment of Arbequina olive cultivar grown in Córdoba province, Argentina," Journal of the Science of Food and Agriculture, vol. 89, no. 3, pp. 523-530, 2009.

[38] Z. D. He, P. P. H. But, T. W. D. Chan et al., "Antioxidative glucosides from the fruits of Ligustrum lucidum," Chemical and Pharmaceutical Bulletin, vol. 49, no. 6, pp. 780-784, 2001.

[39] T. Tanahashi, T. Sakai, Y. Takenaka, N. Nagakura, and C. C. Chen, "Structure elucidation of two secoiridoid glucosides from Jasminum officinale L. var. grandiflorum (L.) Kobuski," Chemical and Pharmaceutical Bulletin, vol. 47, no. 11, pp. 1582-1586, 1999.

[40] D. Caruso, R. Colombo, R. Patelli, F. Giavarini, and G. Galli, "Rapid evaluation of phenolic component profile and analysis of oleuropein aglycon in olive oil by atmospheric pressure chemical ionization-mass spectrometry (APCI-MS)," Journal of Agricultural and Food Chemistry, vol. 48, no. 4, pp. 1182-1185, 2000.

[41] L. Di Donna, F. Mazzotti, A. Napoli, R. Salerno, A. Sajjad, and G. Sindona, "Secondary metabolism of olive secoiridoids. New microcomponents detected in drupes by electrospray ionization and high-resolution tandem mass spectrometry," Rapid Communications in Mass Spectrometry, vol. 21, no. 3, pp. 273278, 2007.

[42] Y. Takenaka, T. Tanahashi, M. Shintaku, T. Sakai, N. Nagakura, and Parida, "Secoiridoid glucosides from Fraxinus americana," Phytochemistry, vol. 55, no. 3, pp. 275-284, 2000.
[43] S. W. Wright, D. L. Hageman, A. S. Wright, and L. D. McClure, "Convenient preparations of t-butyl esters and ethers from tbutanol," Tetrahedron Letters, vol. 38, no. 42, pp. 7345-7348, 1997. 

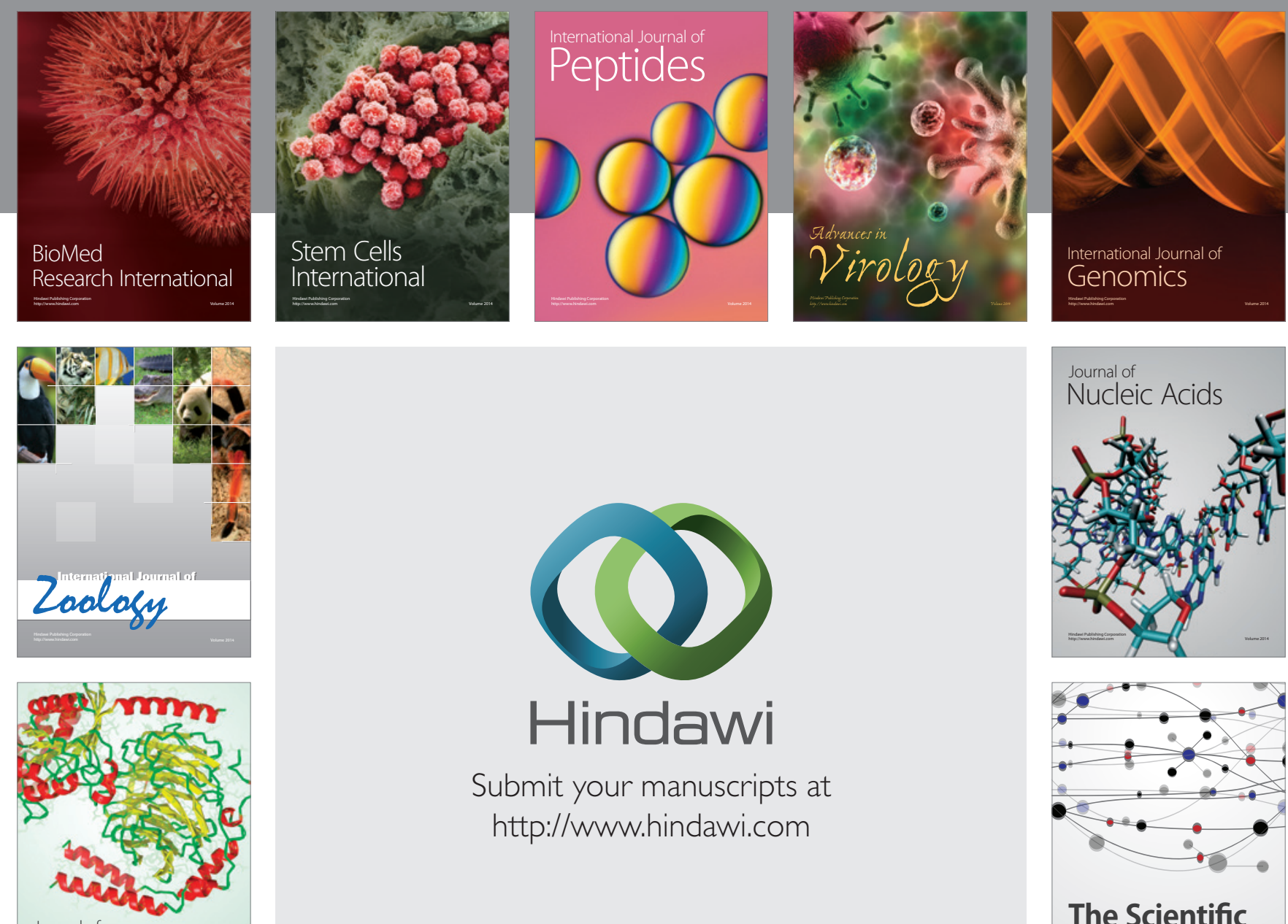

Submit your manuscripts at

http://www.hindawi.com

Journal of
Signal Transduction
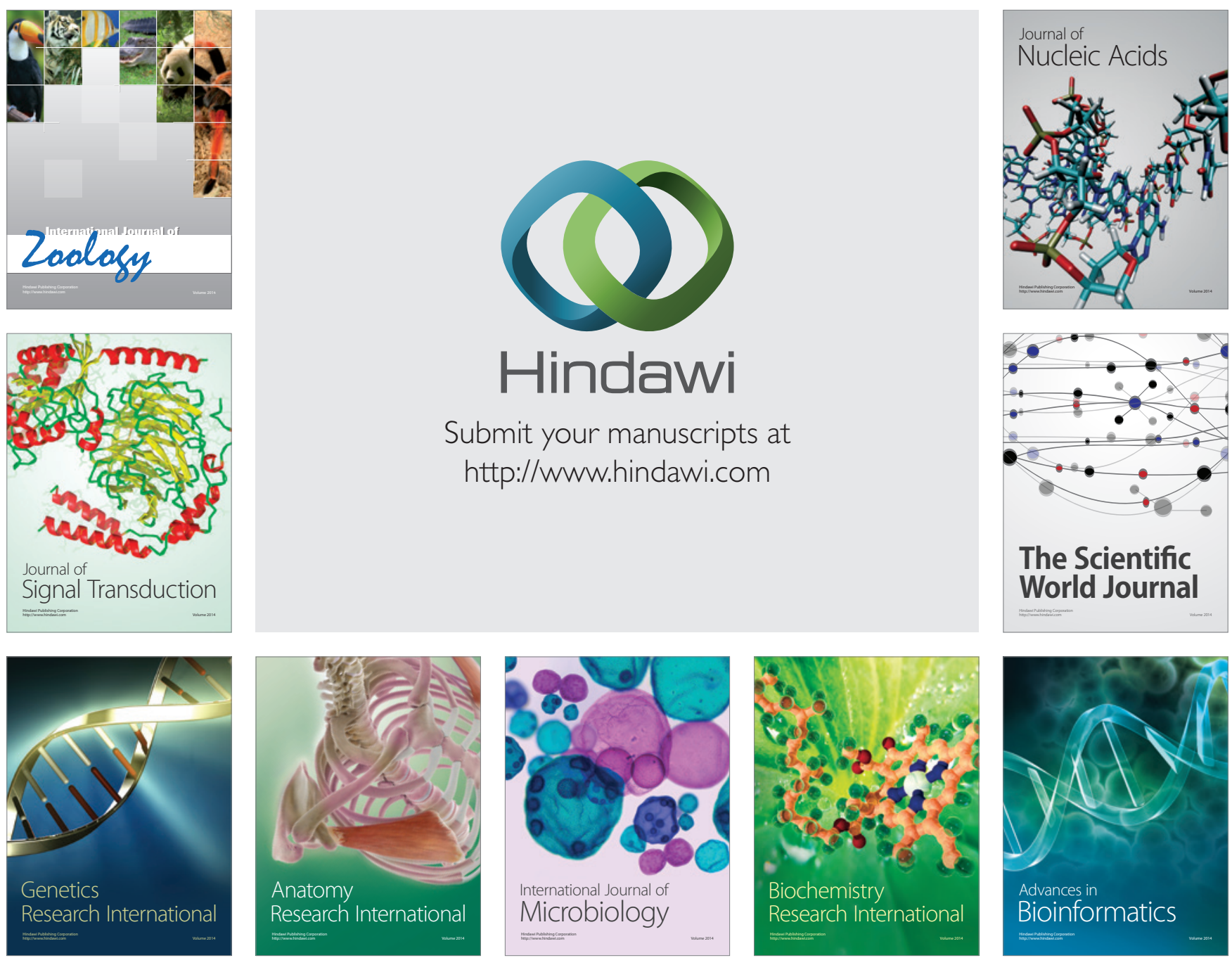

The Scientific World Journal
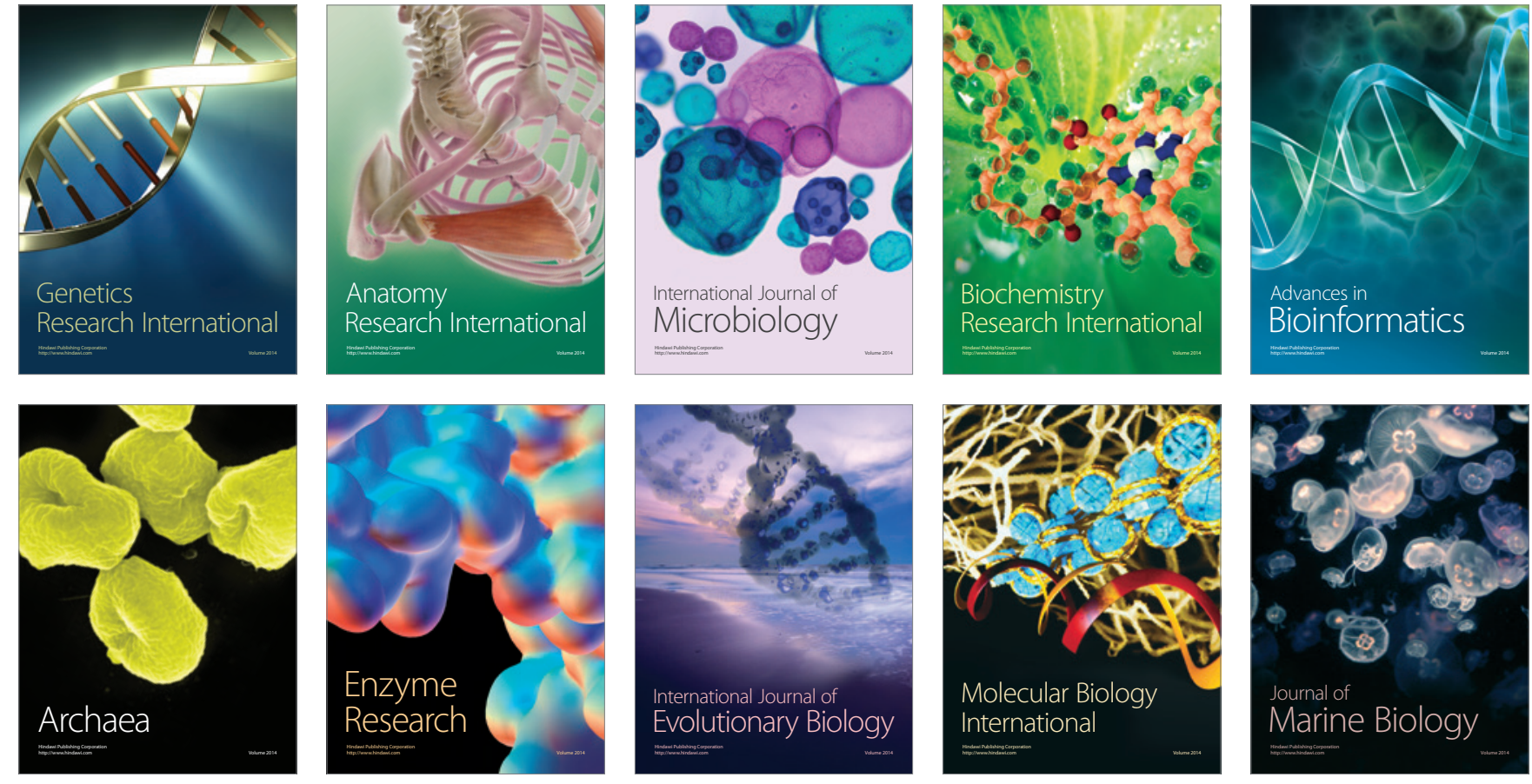